\title{
DNA-based approaches for dairy products authentication: A review and perspectives
}

\author{
Marlene Baptista, Joana T. Cunha, Lucília Domingues \\ CEB - Centre of Biological Engineering, University of Minho, 4710-057, Braga, Portugal
}

\section{A R T I C L E I N F O}

\section{Keywords:}

Authentication methods

Dairy products

Polymerase chain reaction

Species/breed differentiation

Bioinformatic tools

\begin{abstract}
A B S T R A C T
Background: Food fraud has become an increasingly worldwide problem mainly driven by rapid innovation in the food sector and constantly changing consumer's choices. This led to an increased necessity to improve/establish reliable authentication processes, resulting in the replacement of protein-based techniques for dairy products authentication by higher sensitive and reproducible DNA-based methods. Most used molecular methods for dairy products authentication include PCR, Real-time PCR, multiplex PCR, and PCR-RFLP. Despite the several molecular methods available for species/breeds differentiation in dairy products, there is a need for the development of more efficient and reliable molecular tools.

Scope and approach: In this review, traditional and more recent DNA-based methods for dairy products authentication are discussed and analysed. Moreover, the increasingly important role of bioinformatic tools for analysis of large amount of data and for the development of DNA markers is also discussed.

Key findings and conclusions: DNA quality is one of the major factors affecting molecular-based dairy products authentication, which can be influenced by the manufacturing process, extraction method employed, chemical composition of the food matrix, among others. PCR-based methods continue to be the most important and successfully used for dairy products authentication. The DNA markers chosen for species/breed detection are an important factor for PCR success. Although there are several molecular methods for the detection of adulterant species, there is still an unmet demand for methods to detect adulterant breeds. Available public databases and bioinformatics revolutionized the analysis of large amount of data and will be pivotal for the development of effective DNA markers.
\end{abstract}

\section{Introduction}

Food fraud or economically motivated adulteration (EMA), as it is subcategorized by the Food and Drug Administration (FDA), can be generally defined as the intentional deceit in food products for economic gain, although a general definition of food fraud has not yet been established in the US or in Europe (Spink et al., 2019). These adulterations have become an increasingly worldwide problem affecting many consumers mainly driven by rapid innovation in the food sector and constantly changing consumer choices. The magnitude and expansion of food fraud over the globe, however, is not conclusively known since most incidents are not detected. Many types of food fraud events include, according to the Global Food Safety Initiative (GFSI), dilution, substitution, concealment, unapproved enhancement, mislabelling, grey market/theft/diversion, and counterfeiting/intellectual property rights (for more information visit "GFSI, Global Food Safety Initiative: Food
Fraud Technical Document, Tackling Food Fraud through Food Safety Management Systems"). The prevention of food fraud has increasingly been a focus of the agri-food industries and government authorities responsible for ensuring food quality and safety. In this sense, in 2007, the FDA defined a Food Protection Plan based on fraud prevention instead of being based on intervention as a first resource.

Currently, the most adulterated food products include milk and dairy products, mainly due to milk nutritional value, global demand, reduced shelf time and lack of new methods for authentication of these products (Stadler, Tran, Cavin, Zbinden, \& Konings, 2016). Most food fraud cases in milk involve the undeclared substitution of a high-value product (e.g. sheep, buffalo, and goat's milk) with a less expensive or lower quality alternative (e.g. cow milk, milk from less valuable breeds), or the omission of a declared milk species. Also, adulteration with reconstituted milk powder, urea, rennet, among other products (sugar, salt, skim milk powder, among others), can occur. Milk adulteration can also

\footnotetext{
* Corresponding author.

E-mail address: luciliad@deb.uminho.pt (L. Domingues).
} 
happen through the addition of water and supplementation with melamine, which is a toxic compound, resulting in reduced nutritional value (for more information consult "United States Pharmacopeia. Food Fraud Mitigation Guidance, Appendix XVII,” 2014).

Dairy products such as cheese, yogurt, cottage, and cream cheeses are traditional foods in Europe, where they have been consumed by many for centuries. In 2017, 10.2 million tonnes of cheese were produced, being fresh cheese the largest contributor to the total EU production $(34 \%$, or 3.5 million tonnes of cheese) (for more information consult "Where does our cheese come from?", European Commission, 2019). Characteristics of several dairy products in Europe have been associated with the land and manufacturers practices from where they are produced, such as Feta (from Greece), Roquefort (from France), Mozzarella di Bufala Campana (from Italy), Serra da Estrela cheese (from Portugal), among other cheeses. Bearing in mind the protection of the identity of these products as well as other agricultural products, three different labels were created in Europe in Council Regulation (EEC) No 2081/92 of July 14, 1992 (for more information consult "Council Regulation (EEC) No 2081/92 of July 14,1992 on the protection of geographical indications and designations of origin for agricultural products and foodstuffs"): Protected Designation of Origin (PDO), Protected Geographical Indication (PGI), and Traditional Specialties Guaranteed (TSG). These labelled products (PDO, PGI and TSG) are highly prone to adulteration due to their high commercial and nutritional value, texture, flavor and limitation of raw materials. PDO is a label attributed to agricultural products and foodstuffs manufactured in a defined region considering the expertise of the surrounding rural communities. In Europe, there are currently 201 PDO labelled cheeses derived from different countries, being Italy, France, Spain, and Greece the greatest contributors to that number, while other dairy products, such as cottage and cream cheese, only account for 8 products with such designation (for more information consult "Agriculture and Rural Development", European Commission, 2019). PGI, on the other hand, is a label associated with agricultural products or foodstuffs, in which a given step (s) of production, processing or preparation is associated to a specific geographical area, while the raw material used in production can come from another region. Finally, TSG is attributed to agricultural products and foodstuffs that are produced using traditional raw material or production methods, but the final product labelling of origin is not restricted to a given geographical area (Barron, Aldai, Virto, \& de Renobales, 2017).

Even though food safety and authenticity of food products in the supply chains is progressively more ensured in an effective and efficient manner due to the establishment of rigorous food standards (such as British Retail Consortium (BRC) Food, and International Organization for Standardization (ISO) standards), globalization and the growing increase of these chains have increased food fraud cases. Despite the fact that most cases of food fraud do not pose a public health risk, some cases have resulted in serious harm to consumers, such as the scandal of the addition of melanin to milk and infant formulas in China in 2008. Considering those scandals and that food industry is an interconnected system with a worldwide variety of complex relationships between suppliers and consumers, there has been an increasing demand to define a comprehensive and effective system of traceability within the food chain. Food traceability, the ability to access any or all the information related to a food product, over the entire life cycle, through registered identifications, have been used as a tool to comply with the general food legislation (178/2002/EC) of the European Union (EU), which came into force in 2005 and meets the requirements for food and feed safety and quality (Bánáti, 2014).

Protein-based techniques for dairy products authentication (ELISA, isoelectric focusing, and chromatographic techniques) have been replaced by higher sensitive and reproducible DNA-based methods since DNA is more chemical and thermal stable than proteins and thus, withstands food processing. DNA-based methods present clear advances in relation to protein-based methods in terms of time, price, sample amount and sample processing. Moreover, the detection limit between DNA and protein-based methods is similar (Downey, 2016). The preferred molecular method for dairy products authentication is the polymerase chain reaction (PCR), given its utility for analysing DNA molecules.

While several molecular methods have already been developed for species/breeds differentiation in dairy products, the application of these methods for detection of food fraud in traditional products has not been straightforward due to technical process conditions. Considering this and the increased consumer awareness on food fraud, the objectives of this review are to: [1] gather the current molecular methods available for milk breed/species differentiation (end-point PCR, multiplex PCR, real-time PCR, high resolution melting (HRM), DNA hybridization assays, PCR-single strand conformation polymorphisms (PCR-SSCP), isothermal amplification methods, RAPD random amplification of polymorphic DNA (RAPD-PCR), restriction fragment length polymorphism analysis (RFLP)); [2] discuss the technical details involving DNA analysis in different kind of processed dairy products (DNA extraction and the factors influencing DNA-based authentication); and [3] elucidate the impact of next generation sequencing allied to new bioinformatic tools in the development and implementation of novel DNA-based approaches for dairy products authenticity.

\section{DNA extraction methods}

In recent years, DNA-based techniques such as PCR have become powerful tools for food dairy products authentication, namely through specific markers selection. The execution of these techniques requires prior DNA extraction using an appropriate method that allows recovery of quality DNA in high quantity and PCR inhibitors reduction. DNA can be extracted directly from milk somatic cells, since these cells survive processing treatments and are effectively concentrated during cheese production and ripening as well as during milk and other dairy products processing (Lipkin, Shalom, Khatib, Soller, \& Friedmann, 1993). Although genomic DNA can be isolated from somatic cells of ruminant milk species, the recovered amount is sometimes not enough for downstream analysis. This can occur because DNA recovery is dependent on the extraction method chosen and the number of somatic cells present in a given sample. Moreover, the amount of somatic cells present in a milk sample depends on several factors, such as, the breed of an animal, environmental factors (seasons, feeding composition, among others), the lactation stage, health, among other factors. As such, and besides affecting the qualitative detection of fraudulent species/breeds, this variation in the amount of somatic cells present in milk will invariably prevent a quantitative analysis of breed/species in products containing mixtures of different milks (Agrimonti, Bottari, Sardaro, \& Marmiroli, 2019). The composition of dairy products largely influences the efficiency of the DNA extraction. For example, fat content varies between different dairy products ranging from $80 \%$ to $84 \%$ in butter, $25 \%$ in cream and $30 \%$ in cheese. The higher the fat content, the more the extraction DNA procedure will be hampered depending on the method (Sajali et al., 2018). Other factors, such as co-extraction of microbial DNA from the microorganisms involved in dairy processing may also affect the yield of target DNA. The methods used for DNA extraction from dairy products involve common steps such as centrifugation for milk and homogenization for cheese samples preparation, lysis followed by centrifugation, and a variable purification step. Traditional methods used for DNA extraction include phenol-chloroform extraction and salting-out. Easier to use and quicker methods for DNA extraction include silica-based column extraction and magnetic-based extraction. Table 1 summarizes the advantages and disadvantages of the presented methods.

\subsection{Traditional methods}

Phenol chloroform extraction or organic solvent extraction is the classical method used for DNA extraction. Considering the necessity to increase DNA recovery and eliminate inhibitory substances, modifications of the protocol were applied, such as alterations at the level of separation and enrichment of somatic cells in milk and at the level of cell 
Table 1

Summary of the advantages and disadvantages of the DNA extraction methods (traditional and alternative) presented in this review.

\begin{tabular}{|c|c|c|c|}
\hline & Method & Advantages & Disadvantages \\
\hline \multirow[t]{2}{*}{$\begin{array}{l}\text { Traditional } \\
\text { DNA } \\
\text { extraction } \\
\text { methods }\end{array}$} & $\begin{array}{l}\text { Phenol } \\
\text { chloroform } \\
\text { extraction or } \\
\text { organic solvent } \\
\text { extraction }\end{array}$ & $\begin{array}{l}\text { DNA with good } \\
\text { integrity, high } \\
\text { purity, and yield }\end{array}$ & $\begin{array}{l}\text { Use of toxic solvents; } \\
\text { Time-consuming } \\
\text { protocol; } \\
\text { Necessity of sample } \\
\text { transferring between } \\
\text { multiple tubes; } \\
\text { Large scale } \\
\text { application is not } \\
\text { appropriate }\end{array}$ \\
\hline & Salting-out & $\begin{array}{l}\text { Cheap compared } \\
\text { with the rest of the } \\
\text { presented } \\
\text { methods; } \\
\text { Less labour } \\
\text { intensive, quicker, } \\
\text { and safer than } \\
\text { phenol chloroform } \\
\text { method; } \\
\text { DNA integrity is } \\
\text { more preserved } \\
\text { compared to silica- } \\
\text { based column } \\
\text { extraction; }\end{array}$ & $\begin{array}{l}\text { Lower DNA purity } \\
\text { than phenol } \\
\text { chloroform method; } \\
\text { Large volume of milk } \\
\text { sample. }\end{array}$ \\
\hline \multirow[t]{2}{*}{$\begin{array}{l}\text { Alternative } \\
\text { DNA } \\
\text { extraction } \\
\text { methods }\end{array}$} & $\begin{array}{l}\text { Silica-based } \\
\text { extraction }\end{array}$ & $\begin{array}{l}\text { Highly consistent, } \\
\text { efficient and a less } \\
\text { time-consuming } \\
\text { method compared } \\
\text { to phenol- } \\
\text { chloroform; } \\
\text { Incomplete phase } \\
\text { separation is } \\
\text { avoided, resulting } \\
\text { in an increase in } \\
\text { DNA purity }\end{array}$ & $\begin{array}{l}\text { More pronounced } \\
\text { shearing of genomic } \\
\text { DNA, higher cost and } \\
\text { much lower } \\
\text { concentration of DNA } \\
\text { compared to phenol } \\
\text { chloroform method }\end{array}$ \\
\hline & $\begin{array}{l}\text { Magnetic beads- } \\
\text { based extraction }\end{array}$ & $\begin{array}{l}\text { Easily automated, } \\
\text { reduced time of } \\
\text { extraction; }\end{array}$ & $\begin{array}{l}\text { Lower DNA quality } \\
\text { and quantity when } \\
\text { compared to silica- } \\
\text { based extraction; } \\
\text { Shearing of DNA }\end{array}$ \\
\hline
\end{tabular}

lysis (Y. F. Liu, Gao, Yang, Ku, \& Zan, 2014), and combination with Wizard DNA cleanup system kit for DNA purification (López-Calleja, Alonso, et al., 2005). Phenol chloroform extraction involves, firstly, cell lysis and DNA release using sodium dodecylsulfate (SDS) and proteinase K. Next a phenol/chloroform/isoamyl alcohol mixture is added to the cell lysate to separate the proteins from the DNA. After centrifugation, the unwanted proteins and cellular debris present in the organic phase are separated from the aqueous phase containing the DNA molecules. The aqueous phase is then carefully separated without disturbing the interface. Finally, DNA is precipitated and then resuspended in Tris-ethylenediaminetetraacetic acid (EDTA) buffer of ultra-pure water (Psifidi, Dovas, \& Banos, 2010). The advantages of applying this method include the recovery of DNA with good integrity, high purity, and yield. The drawbacks of using this method include the use of toxic solvents, time-consuming protocol, and the need of transferring the sample between multiple tubes. Moreover, large scale application of this method is not appropriate since consistency in the amount of obtained DNA is hard to achieve.

Liao et al. established a novel method for DNA extraction from milk powder. The protocol consisted in the separation of milk cells by centrifugation, followed by a washing step with PBS. The washed sediment was mixed with extraction buffer containing SDS, EDTA and proteinase K. The supernatant was extracted with phenol:chloroform:isoamyl alcohol. The method allowed to obtain $5.3 \mu \mathrm{g}$ DNA/g milk powder, although with low purity (J Liao, Liu, Ku, Liu, \& Huang, 2017). In another study, Liao et al. compared the extraction of DNA from milk samples using an organic solvent method and silica-based column purification kits (StarSpin Blood
DNA and DNeasy Blood and Tissue). Comparing DNA yield values, organic solvent extraction allowed the recovery of a higher amount of DNA per mL of milk sample in relation to the silica-based column extraction. In the matter of purity, the organic solvent extraction resulted in values similar to the ones obtained with DNeay Blood and Tissue kit and higher than StarSpin Blood DNA kit (J Liao \& Liu, 2018). Organic solvent extraction have also been combined with loading of aqueous supernatant in a silica-based column resulting in a successfully DNA extraction from milk and cheese samples, and allowing to obtain high DNA quantity and quality (López-Calleja, Alonso, et al., 2005).

Salting-out emerged as an inexpensive method for DNA extraction. This method is based in the selective precipitation of proteins and other contaminants in the sample when a saturated salt solution (5 or $6 \mathrm{M}$ $\mathrm{NaCl}$ ) is added. After centrifugation, the supernatant containing DNA is separated from the insoluble fraction containing proteins, and after precipitation with pure ethanol or isopropanol the DNA can be resuspended in ultra-pure water or in an appropriate storage buffer. Comparing with the phenol-chloroform extraction method, this method is less labour intensive, quicker, and safer since no toxic solvents are employed, but the purity of DNA obtained is lower (D'Angelo, Santillo, Sevi, \& Albenzio, 2007; J Liao, Liu, Yang, Li, \& Sheppard, 2017). On the other hand, DNA integrity is more preserved compared to silica-based column extraction (Kovačević, 2016). A salting-out method was developed by D'Angelo et al. for DNA extraction from caprine milk samples, obtaining yields that ranged from 2.12 to $612.12 \mu \mathrm{g}$ per $40 \mathrm{~mL}$ of raw milk sample. Although the developed method is simple and quick, drawbacks of its application include the large volume of milk sample used and the flawed downstream application of the extracted DNA, since only 6 out of 8 tested samples were suitable as a substrate for PCR-RFLP genotyping (D’Angelo et al., 2007).

\subsection{Alternative methods}

Silica-based methods involve the use of a chaotropic agent, such as guanidinium chloride in the cell lysis buffer, resulting in the selective and reversible DNA binding to a silica matrix present in a column. The silica-DNA bound complexes can be subsequently washed with an alcohol solution to remove contaminants (in the case of dairy samples may be proteins, RNA, and fat) and then the DNA eluted using water or Tris-EDTA buffer. The yield of DNA depends on the type of dairy sample analysed, the volume of sample used and buffer composition.

Several commercial kits comprising silica-based columns and chemicals are available and many authors compared their efficiency for DNA extraction from milk and cheese samples (Díaz et al., 2007; Psifidi et al., 2010). Díaz et al. reported the use of a Wizard DNA clean-up kit (Promega, Madison, WI) after cell lysis overnight and were able to detect cow milk in goat cheeses through the amplification of 12S rRNA gene of goat (Díaz et al., 2007). In another study, 6 different protocols for DNA extraction from milk samples including two kits (NucleoSpin Blood and NucleoSpin Tissue (Macherey-Nagel GmbH \& Co. KG, Duren, Germany)) and two modified protocols of the kits were compared to phenol-chloroform extraction and an in-house protocol. The modifications to the kits involved the introduction of two additional steps to eliminate PCR inhibitors. The first modification included the addition of a TE (Tris-EDTA) solution to milk somatic cells with the objective of dissolving casein, while the second modification involved the addition of chloroform after cell lysis to remove lipids present in milk. The in-house protocol involved the use of guanidinium hydrochloride instead of proteinase $\mathrm{K}$ in cell lysis and the application of a silica-based affinity matrix for DNA purification. According to the spectrophotometric measurements (Abs 260/280 and 260/230), modified protocols of the two commercial kits allowed to obtain better purity results comparing with the other tested methods. The suitability of the extracted DNA for downstream applications was evaluated by real-time PCR and it was verified that the two modified kits were the most satisfactory in terms of DNA amount (Psifidi et al., 2010). 
Maudet et al. used the DNeasy Blood and Tissue kit based on silicacolumn extraction for DNA isolation from goat and cow cheeses. PCR amplification of D-loop region was possible even when DNA was extracted from pasteurized cheese. In this study, spin column-based extraction efficiently removed PCR inhibitors and allowed DNA recovery in sufficient amount for PCR amplification (Maudet \& Taberlet, 2001). Bottero et al. (2003) also used DNeasy Blood and Tissue Kit for DNA extraction from cheese samples and were able to apply the extracted DNA in a multiplex PCR reaction being able to detect bovine, caprine, and ovine species in milk mixtures (Bottero et al., 2003).

Spin-column based extraction is highly consistent, efficient and a less time-consuming method compared to phenol-chloroform. Moreover, complications related to incomplete phase separation when performing phenol-chloroform extraction are avoided. However, comparing to phenol-chloroform method some drawbacks can be pointed, such as, more pronounced shearing of genomic DNA, higher cost and much lower concentration of DNA obtained.

Magnetic beads-based extraction consists on the binding of DNA to the surface of charged paramagnetic particles in the presence of a buffer containing a chaotropic salt. DNA can be separated from other impurities present in the sample in the presence of a magnet. Drawbacks of using this method include shearing of DNA and low purity (Kovačević, 2016). When a large number of samples need to be processed this method can be easily automated, considerably reducing time for extraction. However, Di Pinto et al. compared the application of a paramagnetic-based extraction kit (Wizard Magnetic DNA Purification for Food, Promega Italia S.r.l., Milano, Italy) with a column-based extraction kit (DNeasy Tissue Kit, QIAGEN, Hilden, Germany) for DNA extraction from pasteurized milk samples and verified that DNeasy Tissue Kit allowed to obtain higher DNA quantity and quality (Di Pinto et al., 2007).

\section{Factors influencing DNA-based authentication methods}

DNA is a highly stable molecule and is one of the most reliable markers for food products authentication. However, several steps upstream the application of molecular techniques can influence DNA quality and may compromise the analysis (Fig. 1).

\subsection{DNA integrity and food processing}

Different downstream molecular methods chosen for authentication will require different degree of DNA integrity, depending on the size of the fragment to be detected. Amplification of longer DNA fragments is hindered in cheeses because DNA is sometimes degraded (Feligini et al., 2005). Rentsch et al. verified that long periods of time of cheese ripening result in losses of amplifiable DNA comparing to fresh cheeses, probably because of DNA degradation. Even though DNA yields obtained from cheese samples may be higher than the ones obtained from milk, this may not represent an increase in amplifiable DNA because of the contribution of bacterial DNA and degraded DNA resulting from cheese ripening (Rentsch et al., 2013).

Furthermore, the manufacturing process of many dairy products (UHT skimmed milk, butter, cheese, yoghurt, cream, and others) involve essentially the application of heat treatment for shelf life extension. These treatments cause the degradation of DNA molecules (J. Liao, Yang, Sheppard, \& Liu, 2018). In terms of purity and PCR inhibitors presence, lower purity of DNA was observed in heat-treated milk powder due to denatured proteins that can co-precipitate with genomic DNA, comparing with DNA purity obtained from raw milk (J Liao, Liu, Ku, et al., 2017). However, Maudet et al. were able to amplify cow specific mitochondrial DNA (mtDNA) in goat cheeses with high ripening time, made with heat treated (UHT) or pasteurized milk, and after freezing of the cheese for several months. Nevertheless, information about DNA quality parameters are not presented in the study (Maudet \& Taberlet, 2001).

Whole genome amplification (WGA) has appeared as a valuable tool to solve the problem of limited or insufficient DNA quantity for downstream analysis (Mendes Silva \& Domingues, 2015). WGA increases both the quality (amplifiability) and quantity of DNA (from nanograms into micrograms quantities), and has been successfully used in several genomic analysis such as: cattle genotyping assays (Moghaddaszadeh-Ahrabi, S Farajnia, Rahimi-Mianji, \& Nejati-Javaremi, 2012), including the use of milk samples (Moghaddaszadeh-Ahrabi, S Farajnia et al., 2012); and dairy cattle genomic selection (Yudin, Lukyanov, Voevoda, \& Kolchanov, 2016). Despite the lack of reports of WGA

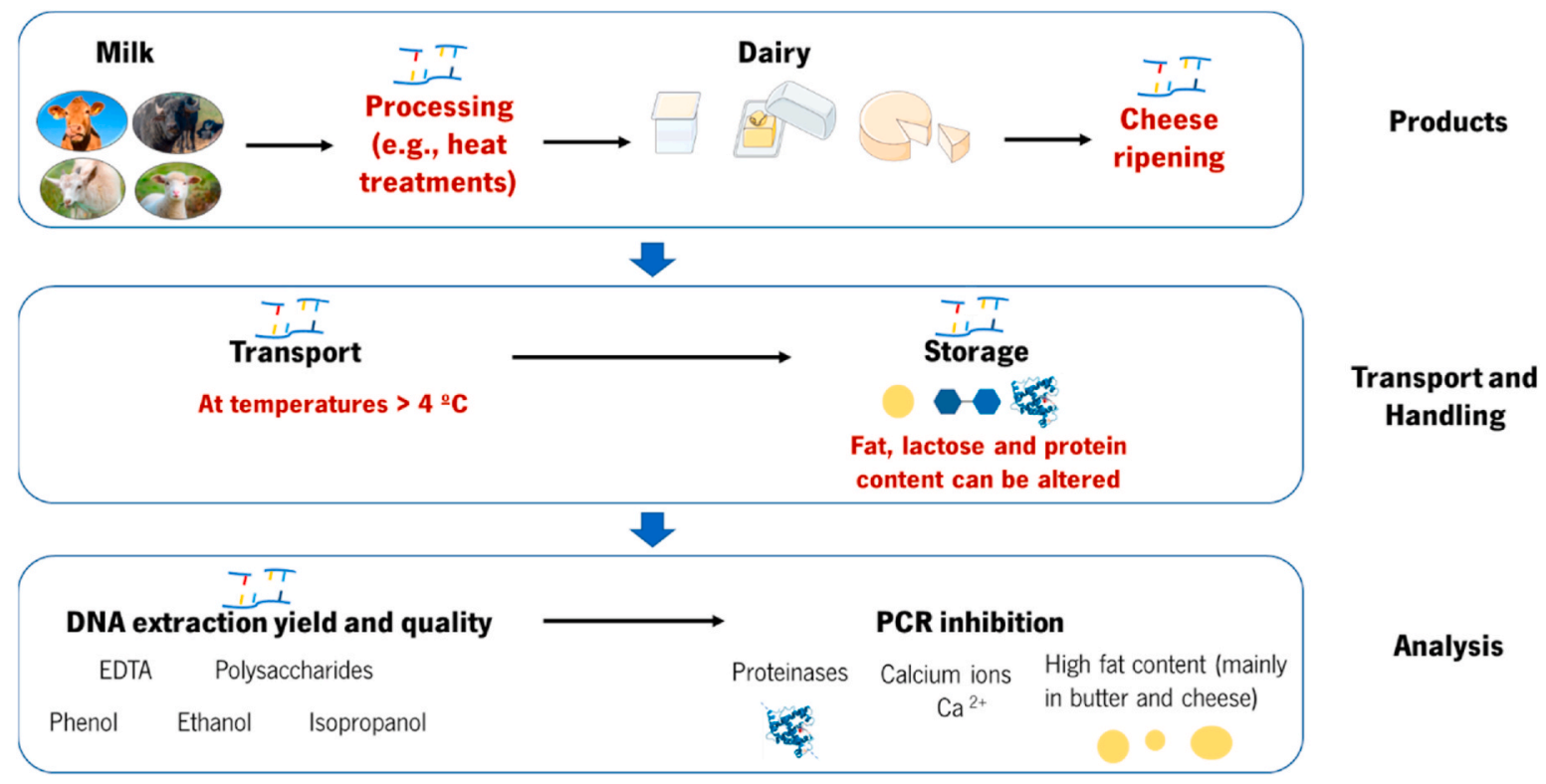

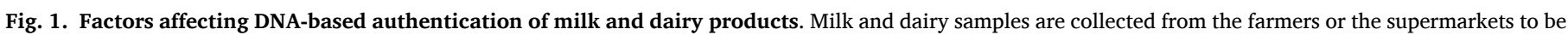

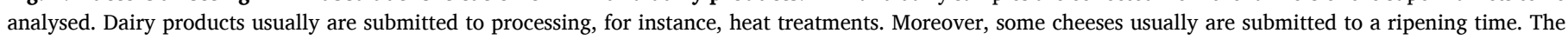

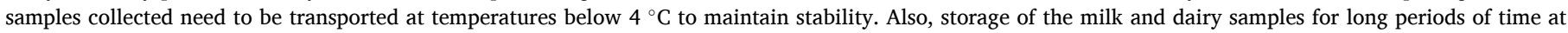

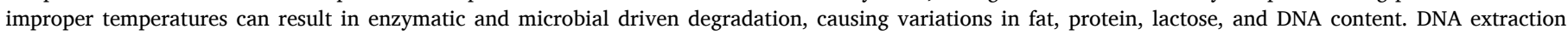

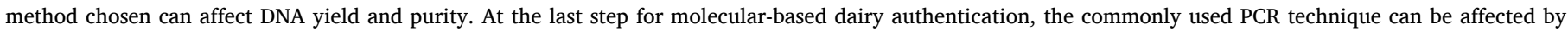
several inhibitors. 
application for dairy authentication, this method is a promising tool to improve the accuracy and reproducibility of PCR-based methods for analysis of processed dairy products.

\section{2. $P C R$ inhibitors}

Milk and dairy products present constituents that can inhibit the performance of PCR reaction. Components of milk and dairy products responsible for PCR inhibition include proteinases and high content of fat (mainly in cheese and butter). Calcium ions present in milk have also been identified as a source of PCR inhibition. Moreover, the extraction method used may also contribute to the presence of inhibitors in the final samples that will affect DNA analysis. Components of DNA extraction samples that are recognised as PCR reaction inhibitors include chelators, such as EDTA, which can complex the $\mathrm{Mg}^{2+}$ ions that are necessary for polymerase activity; polysaccharides, which can directly bind to the single- or doubled-stranded DNA or the magnesium cofactor; phenol, which causes denaturation of the polymerase; and ethanol and isopropanol, which cause precipitation of DNA (Schrader, Schielke, Ellerbroek, \& Johne, 2012).

\subsection{Biological and DNA-sample handling}

Considering that the development and application of molecular methods for food products authentication is not performed by the producers in the manufacturing facilities and requires specialized laboratory equipment and personnel, biological samples must be transported carefully from the collection place (farm or manufacturing plant) to the laboratory. Milk and dairy products must be transported on ice packs (to maintain a low temperature around $4{ }^{\circ} \mathrm{C}$ ) to the laboratory and preferentially processed immediately or stored at $-80^{\circ} \mathrm{C}$ until used. However, long-term storage and improper storage temperature result in enzymatic and microbial driven degradation of these products. Milk physical and chemical features (fat, protein, and lactose content) can be altered during storage at 2,10 and $20^{\circ} \mathrm{C}$. At these temperatures, the DNA content in the samples decreases, but the purity remains unchanged (Liao et al., 2018).

\section{Current molecular techniques for dairy products authentication}

Dairy industry worldwide presents products with high market value most of the times associated with origin labels, such as cheeses made with goat and sheep milk, that are common targets of adulteration with lower market value products, such as cow milk.

Livestock species genomes have changed over centuries driven by natural causes or human hand. Domesticated livestock species, such as cattle, goat, and sheep, have evolved into more or less distinct breeds, traditionally used as the basis of genetic diversity conservation. A breed can be defined as a specific population belonging to a specie that is selectively bred to preserve some characteristics, such as coat colour. Genetic variations resulting from this selection are usually characterized by high genetic distinction between breeds (Eusebi, Martinez, \& Cortes, 2020).

Different methods need to be adopted to differentiate between species and breeds, reflecting the genetic variations between them. The efficiency of most of these methods depends, among many other factors, on the study of genetic regions that are sufficiently different between species or breeds but similar enough between individuals from de same species or breed. DNA-based methods developed so far for species and breed differentiation to assist dairy products authentication will be described below and are summarized in Table 2.

\subsection{Species-differentiation techniques}

PCR became the most widely used method for the detection of the animal origin in dairy products. The amplification of genomic DNA using universal or species-specific primers through a PCR reaction is of utmost importance for dairy products authentication. Both nuclear and mtDNA can be used for PCR-based authentication of dairy products, although mtDNA is most commonly used since its sequence is highly conserved within a specie, sequences from different species can be found in public databases and it is present in high copy number in animal cells, resulting in an increased specificity and detection capacity (F. Pereira, Amorim, \& Asch, 2013).

PCR was first used for milk authentication by Plath et al. in a study where RFLP analysis and polyacrylamide gel electrophoresis were used to identify bovine milk in ovine or caprine milk and cheeses (Plath, Krause, \& Einspanier, 1997). PCR-RFLP is a simple and low-cost method that consists firstly in the amplification of a DNA sequence, followed by the digestion of the PCR product by restriction enzymes resulting in a pattern of fragments that can be obtained by electrophoretic separation (Pereira et al., 2013). PCR-RFLP followed by agarose gel electrophoresis was used latter by Abdel-Rahman et al. for identification and detection of buffalo's, cattle's, and sheep's milk. In that study, cytochrome $b$ gene amplified from mtDNA was successfully used to differentiate buffalo's and cattle's milk, while amplification of the species-specific repeat (SSR) gene also isolated from mtDNA allowed the detection of buffalo's or cattle's milk in sheep's milk (Abdel-Rahman \& Ahmed, 2007).

PCR amplification of different species-specific targets followed by agarose gel electrophoresis separation according to amplicons size and finally visualization using a DNA dye has been one of the most used methods for dairy products authentication due to its simplicity and reduced labour time. This technique was used to detect goat's milk in sheep's milk with a sensitivity of $0.1 \%$. After alignment of $12 \mathrm{~S}$ rRNA gene from goat, sheep, cow and water buffalo sequences, a goat-specific primer pair was designed to amplify a $122 \mathrm{bp}$ fragment allowing the detection of goat DNA in sheep milk samples. A sheep-specific primer pair was designed to verify the presence of a sheep-specific fragment of $317 \mathrm{bp}$ and serve as a positive amplification control of PCR (López-Calleja et al., 2005). Later this technique was used by Mašková and Paulícková to detect above $1 \%$ of cow's milk in goat and sheep cheeses from five different European countries. This PCR method is based on the design of reverse species-specific primers and the use the same forward primer targeted to amplify the mitochondrial gene coding cytochrome $b$ which is specific for mammals. Separation of PCR products resulted in the detection of a cow specific fragment of $274 \mathrm{bp}$, a goat specific fragment of $157 \mathrm{bp}$, and a sheep specific fragment of $331 \mathrm{bp}$ (Maškova \& Paulíčková, 2006). Maudet el al. applied for the first time a PCR reaction to detect as less as $0.1 \%$ of cows' milk in goat cheeses from French markets. In this study, two universal primers based on the control region sequence of mtDNA were used to amplify a cow fragment of 724 bp and a goat fragment of $987 \mathrm{bp}$. Cow specific primers were also designed to ensure that goat mtDNA was not amplified. These primers were designed between specific positions of the mtDNA within an area with several deletions comparing cow to sheep sequences, allowing the detection of a cow-specific fragment of 413 bp (Maudet \& Taberlet, 2001). Later in 2009, Bai et al. developed a PCR method for specific identification of as little as $0.1 \%$ of cow milk in yak raw and heat-treated binary mixtures of milk. Based on the alignment of mtDNA of bovine and yak, a primer pair targeting the ND1 gene of both species was designed and served as a positive control, allowing the amplification and detection of a 293 bp fragment in both species. Moreover, a bovine-specific forward primer was designed within the potential region amplified when the previous primer pair is used. The combination of cow-specific forward and cow/goat reverse primers resulted in the amplification of a 190 bp fragment in cow but not in yak, which allows unequivocal determination of bovine in yak milk samples (Bai et al., 2009).

Bottero et al. are among the few authors that developed a multiplex PCR for simultaneous detection of several species in dairy products in a multiplex reaction. The authors developed a multiplex reaction with $0.5 \%$ detection limit for the simultaneous detection of cows', goats' and 
Table 2

Summary of DNA-based techniques for dairy products authentication.

\begin{tabular}{|c|c|c|c|c|c|}
\hline \multirow[b]{2}{*}{ Technique } & \multicolumn{5}{|l|}{ Species differentiation } \\
\hline & Objective of the analysis & Type of dairy sample & DNA target & Detection limit & ref \\
\hline $\begin{array}{l}\text { PCR-RFLP/ } \\
\text { polyacrylamide gel } \\
\text { electrophoresis }\end{array}$ & $\begin{array}{l}\text { Identification of cow's milk in ewe's } \\
\text { and goat's milk cheese }\end{array}$ & $\begin{array}{l}\text { Fresh milk and cheese containing } \\
\text { defined amounts of raw, } \\
\text { pasteurized or UHT-treated cow's } \\
\text { milk or whey proteins }\end{array}$ & $\begin{array}{l}\text { Partial sequence of the } \\
\beta \text {-casein gene }\end{array}$ & $0.5 \%$ of cow milk & Plath et al. (1997) \\
\hline $\begin{array}{l}\text { PCR-RFLP/Agarose gel } \\
\text { electrophoresis }\end{array}$ & $\begin{array}{l}\text { Identification and detection of } \\
\text { buffalo's, catttle's and sheep's milk }\end{array}$ & Fresh milk & $\begin{array}{l}\text { Species-specific repeat } \\
\text { (SSR) and the gene } \\
\text { encoding cytochrome-b }\end{array}$ & - & $\begin{array}{l}\text { Abdel-Rahman and } \\
\text { Ahmed (2007) }\end{array}$ \\
\hline $\begin{array}{l}\text { PCR/agarose gel } \\
\text { separation }\end{array}$ & $\begin{array}{l}\text { Detection of adulteration of sheep's } \\
\text { milk with goats' milk }\end{array}$ & Raw milk & $\begin{array}{l}\text { 12S rRNA gene } \\
\text { fragment }\end{array}$ & $0.1 \%$ of goat milk & $\begin{array}{l}\text { López-Calleja, } \\
\text { González, et al. } \\
\text { (2005) }\end{array}$ \\
\hline $\begin{array}{l}\text { PCR/agarose gel } \\
\text { separation }\end{array}$ & $\begin{array}{l}\text { Detection of cow's milk in goat and } \\
\text { sheep cheese }\end{array}$ & Cheese & Cytochrome $b$ gene & $1 \%$ of cow milk & $\begin{array}{l}\text { Maškova \& } \\
\text { Paulíčková (2006) }\end{array}$ \\
\hline PCR/agarose gel detection & $\begin{array}{l}\text { Detection of goats' milk in ewes' } \\
\text { cheeses }\end{array}$ & Cheese & 12S rRNA gene & $1 \%$ of goat milk & Díaz et al. (2007) \\
\hline $\begin{array}{l}\text { PCR/agarose gel } \\
\text { electrophoresis }\end{array}$ & $\begin{array}{l}\text { Detection of cows' milk in goat } \\
\text { cheese }\end{array}$ & $\begin{array}{l}\text { Cheeses made with unpasteurized, } \\
\text { pasteurized or UHT-treated cows' } \\
\text { or mixed milk (cow and goat or } \\
\text { ewe) }\end{array}$ & $\begin{array}{l}\text { D-loop mitochondrial } \\
\text { gene }\end{array}$ & $0.1 \%$ of cow milk & $\begin{array}{l}\text { Maudet and Taberlet } \\
\text { (2001) }\end{array}$ \\
\hline $\begin{array}{l}\text { PCR/agarose gel } \\
\text { electrophoresis }\end{array}$ & $\begin{array}{l}\text { Detection of cows' milk in buffalo } \\
\text { cheese }\end{array}$ & Mozzarella cheese & Cytochrome $b$ gene & $1.5 \%$ of cow milk & $\begin{array}{l}\text { Di Pinto, Conversano, } \\
\text { Forte, Novello, and } \\
\text { Tantillo (2004) }\end{array}$ \\
\hline $\begin{array}{l}\text { PCR/agarose gel } \\
\text { electrophoresis }\end{array}$ & $\begin{array}{l}\text { Detect cows' milk in water buffalo } \\
\text { Mozzarella cheese }\end{array}$ & Mozzarella cheese & $\begin{array}{l}\text { Cytochrome oxidase } \\
\text { subunit } \\
\text { I (COI) gene }\end{array}$ & $0.5 \%$ of cow milk & Feligini et al. (2005) \\
\hline $\begin{array}{l}\text { PCR/agarose gel } \\
\text { electrophoresis }\end{array}$ & Detect cows' milk in yak milk & $\begin{array}{l}\text { Raw and heat-treated milk } \\
\text { mixtures }\end{array}$ & $\begin{array}{l}\text { NADH-ubiquinone } \\
\text { oxidoreductase chain } 1 \\
\text { encoding gene (ND1) }\end{array}$ & $0.1 \%$ of cow milk & Bai et al. (2009) \\
\hline $\begin{array}{l}\text { PCR/Capillary } \\
\text { electrophoresis }\end{array}$ & $\begin{array}{l}\text { Detection of cattle, sheep, goat, and } \\
\text { water buffalo species in milk and } \\
\text { dairy products. } \\
\text { Detection of cows' milk in buffalo } \\
\text { milk for determination of limit of } \\
\text { detection. }\end{array}$ & Blood, raw milk and cheese & $\kappa$-casein gene & $0.1 \%$ of cow milk & Reale et al. (2008) \\
\hline Real-time Taqman PCR & $\begin{array}{l}\text { Detection and quantification of } \\
\text { cows' milk in buffalo cheese }\end{array}$ & Blood, raw milk and cheese & $\begin{array}{l}\text { Cytochrome } b \text { and } \\
\text { nuclear growth } \\
\text { hormone }(\mathrm{GH}) \text { genes }\end{array}$ & $0.1 \%$ of cow milk & $\begin{array}{l}\text { Lopparelli et al. } \\
\text { (2007) }\end{array}$ \\
\hline Real-time Taqman PCR & $\begin{array}{l}\text { Quantification of goats' milk in } \\
\text { sheep's milk mixtures }\end{array}$ & Binary raw milk mixtures & 12S rRNA gene & $0.6 \%$ of goat milk & $\begin{array}{l}\text { López-Calleja et al. } \\
\text { (2007) }\end{array}$ \\
\hline Real-Time Taqman PCR & $\begin{array}{l}\text { Detection of cows' milk in buffalo } \\
\text { milk }\end{array}$ & Blood, raw milk and cheese & Cytochrome $b$ gene & $2 \%$ of cow milk & $\begin{array}{l}\text { Dalmasso, Civera, La } \\
\text { Neve, and Bottero } \\
\text { (2011) }\end{array}$ \\
\hline Real-time Taqman PCR & $\begin{array}{l}\text { Identification of cattle, buffalo, } \\
\text { sheep, and goat species in milk and } \\
\text { dairy products }\end{array}$ & $\begin{array}{l}\text { Binary raw milk mixtures and } \\
\text { cheese }\end{array}$ & Cytochrome $b$ gene & $\begin{array}{l}<1 \% \text { of cow, } \\
\text { goat, sheep and } \\
\text { buffalo milk }\end{array}$ & $\begin{array}{l}\text { Di Domenico, Di } \\
\text { Giuseppe, Wicochea } \\
\text { Rodríguez, and } \\
\text { Cammà (2017) }\end{array}$ \\
\hline $\begin{array}{l}\text { Real-time PCR } \\
\text { Intercalating } \\
\text { Fluorescent Dye }\end{array}$ & $\begin{array}{l}\text { Detection of cow milk in goat milk } \\
\text { powder }\end{array}$ & Whole milk powder & $\begin{array}{l}\text { Cytochrome } b \text { gene and } \\
\text { ATP6 gene }\end{array}$ & $0.1 \%$ of cow milk & $\begin{array}{l}\text { (J Liao, Liu, Ku, et al., } \\
\text { 2017) }\end{array}$ \\
\hline $\begin{array}{l}\text { Quadruplex Real-time } \\
\text { PCR/Taqman probes }\end{array}$ & $\begin{array}{l}\text { Detection of cow milk in ewe's and } \\
\text { goat's cheese }\end{array}$ & Milk, cheese and yoghurt & $\begin{array}{l}\text { Cow species nuclear } \\
\text { targets and sheep, goat } \\
\text { and water buffalo } \\
\text { cytochrome } b \text { gene }\end{array}$ & $0.2 \%$ of cow milk & Rentsch et al. (2013) \\
\hline $\begin{array}{l}\text { Quadruplex real-time } \\
\text { PCR/HRM analysis }\end{array}$ & $\begin{array}{l}\text { Identification of cow, goat, sheep } \\
\text { and buffalo species in dairy } \\
\text { products and quantification of cow } \\
\text { milk in the same products }\end{array}$ & $\begin{array}{l}\text { Mixes of milks, cheeses prepared } \\
\text { with the same mixes and } \\
\text { commercial dairy products }\end{array}$ & $\begin{array}{l}\text { Cytochrome } b \text { gene and } \\
12 S \text { rRNA }\end{array}$ & $0.1 \%$ of cow milk & $\begin{array}{l}\text { Agrimonti et al. } \\
(2015)\end{array}$ \\
\hline multiplex qPCR & $\begin{array}{l}\text { Detection of cow milk in buffalo } \\
\text { milk, and vice versa }\end{array}$ & Raw milk & Cytochrome $b$ gene & $\begin{array}{l}1 \% \text { of cow milk } \\
1 \% \text { of buffalo } \\
\text { milk }\end{array}$ & $\begin{array}{l}\text { Cottenet, Blancpain, } \\
\text { and Golay (2011) }\end{array}$ \\
\hline multiplex qPCR & $\begin{array}{l}\text { Identification of goat, sheep and } \\
\text { cow species in dairy products }\end{array}$ & Blood samples and cheese & 12s rRNA and 16s rRNA & $0.5 \%$ of cow milk & Bottero et al. (2003) \\
\hline $\begin{array}{l}\text { Quadruplex PCR/ } \\
\text { Capillary } \\
\text { electrophoresis }\end{array}$ & $\begin{array}{l}\text { Identification of cow, goat, sheep, } \\
\text { and water buffalo in dairy products }\end{array}$ & $\begin{array}{l}\text { Standard cheese, PDO cheese, } \\
\text { cottage cheese, powdered milk, } \\
\text { UHT milk, fresh milk, yogurt, } \\
\text { cream, and butter }\end{array}$ & MtDNA target regions & $\begin{array}{l}1 \% \text { of cow, } \\
\text { buffalo, goat and } \\
\text { sheep milk }\end{array}$ & $\begin{array}{l}\text { Gonçalves, Pereira, } \\
\text { Amorim, and van } \\
\text { Asch (2012) }\end{array}$ \\
\hline Triplex qPCR & $\begin{array}{l}\text { Identification of bovine and equine } \\
\text { DNA in milk and dairy products }\end{array}$ & $\begin{array}{l}\text { Fresh meat samples of beef, horse, } \\
\text { mutton, pork, chicken, duck, } \\
\text { goose, dog, rabbit, cat, and carp, } \\
\text { cow and mare milk, yogurt, } \\
\text { koumiss, and sour soup }\end{array}$ & 12S rRNA gene & $\begin{array}{l}1 \text { pg of DNA (cow } \\
\text { milk, yogurt, and } \\
\text { mare milk), } 5 \text { pg } \\
\text { of DNA (sour } \\
\text { soup and } \\
\text { koumiss) }\end{array}$ & Guo et al. (2018) \\
\hline Duplex qPCR & $\begin{array}{l}\text { Detection of both cows' and goats' } \\
\text { milk in goats' milk cheeses }\end{array}$ & & 12S rRNA gene & $0.1 \%$ of cow milk & $\begin{array}{l}\text { Mafra, Roxo, Ferreira, } \\
\text { and Oliveira (2007) } \\
\text { (continued on next page) }\end{array}$ \\
\hline
\end{tabular}


Table 2 (continued)

\begin{tabular}{|c|c|c|c|c|c|}
\hline \multirow[b]{2}{*}{ Technique } & \multicolumn{5}{|l|}{ Species differentiation } \\
\hline & Objective of the analysis & Type of dairy sample & DNA target & Detection limit & ref \\
\hline & & $\begin{array}{l}\text { Samples of soft and ripened } \\
\text { cheeses containing raw or } \\
\text { pasteurized milk }\end{array}$ & & & \\
\hline Duplex PCR & $\begin{array}{l}\text { Detection of cows' milk in goat } \\
\text { cheese }\end{array}$ & Blood samples and cheese & 12S rRNA gene & $0.5 \%$ of cow milk & Golinelli et al. (2014) \\
\hline Duplex PCR & $\begin{array}{l}\text { Detection of cow milk in camel, } \\
\text { horse, and goat milk }\end{array}$ & $\begin{array}{l}\text { Binary mixtures of raw milk fixed } \\
\text { percentage and processed dairy } \\
\text { products (freeze-dried, } \\
\text { pasteurized, and UHT sterilized } \\
\text { with the same mixtures and } \\
\text { commercial samples) }\end{array}$ & $\begin{array}{l}\text { 16S-RNA genes from } \\
\text { camel and cow and D- } \\
\text { LOOP genes from horse } \\
\text { and goat }\end{array}$ & $\begin{array}{l}0.1 \% \text { of cow milk } \\
\text { in raw milk } \\
\text { mixture }\end{array}$ & Deng et al. (2020) \\
\hline $\begin{array}{l}\text { Real-time PCR } \\
\text { HRM analysis }\end{array}$ & $\begin{array}{l}\text { Identification of cow milk in cheese } \\
\text { and quantification of the ratio of } \\
\text { sheep to goat milk mixture in cheese }\end{array}$ & $\begin{array}{l}\text { Blood samples, raw milk and } \\
\text { cheese }\end{array}$ & MtDNA D-loop & $\begin{array}{l}0.1 \% \text { of cow milk } \\
1 \% \text { of caprine and } \\
\text { ovine milk }\end{array}$ & $\begin{array}{l}\text { Ganopoulos et al. } \\
\text { (2013) }\end{array}$ \\
\hline $\begin{array}{l}\text { PCR/DNA hybridization } \\
\text { on fluorescent } \\
\text { microspheres }\end{array}$ & $\begin{array}{l}\text { Detection of cow milk in goat and } \\
\text { sheep dairy products }\end{array}$ & Low-fat yogurt & Cytochrome $b$ gene & $\begin{array}{l}0.01 \% \text { of cow } \\
\text { milk in goat's } \\
\text { milk } \\
0.05 \% \text { of cow } \\
\text { milk in sheep's } \\
\text { milk }\end{array}$ & $\begin{array}{l}\text { Kounelli and } \\
\text { Kalogianni (2017) }\end{array}$ \\
\hline $\begin{array}{l}\text { PCR/DNA Hybridization } \\
\text { assay on a biochip }\end{array}$ & $\begin{array}{l}\text { Detection of cattle, goat and Buffalo } \\
\text { species in milk }\end{array}$ & $\begin{array}{l}\text { Raw/pasteurized, and heated } \\
\text { meat and milk }\end{array}$ & $\begin{array}{l}\text { Cytochrome } b \text { oxidase } \\
\text { gene }\end{array}$ & $\begin{array}{l}0.1 \% \text { of cattle, } \\
\text { goat and Buffalo } \\
\text { milk }\end{array}$ & Beltramo et al. (2017) \\
\hline PCR-SSCP & $\begin{array}{l}\text { Identification of cattle, buffalo, } \\
\text { sheep, and goat in milk and cheese }\end{array}$ & Raw milk and cheese & 12S rRNA gene & $3 \%$ of cow milk & Csikos et al. (2016) \\
\hline $\begin{array}{l}\text { Next generation } \\
\text { sequencing (NGS) }\end{array}$ & $\begin{array}{l}\text { Identification of cow, goat, sheep } \\
\text { and buffalo in milk mixtures and } \\
\text { cheeses }\end{array}$ & Milk mixtures and cheese & $\begin{array}{l}12 \mathrm{~S} \text { and } 16 \mathrm{~S} \\
\text { mitochondrial rRNA } \\
\text { genes }\end{array}$ & - & Ribani et al. (2018) \\
\hline $\begin{array}{l}\text { Loop-mediated isothermal } \\
\text { amplification (LAMP) }\end{array}$ & $\begin{array}{l}\text { Simultaneous identification of cow } \\
\text { milk in goat milk and vice versa }\end{array}$ & Milk and yogurt & Cytochrome $b$ gene & $\begin{array}{l}2 \% \text { of cow and } \\
\text { goat milk }\end{array}$ & Kim and Kim (2018) \\
\hline $\begin{array}{l}\text { Recombinase polymerase } \\
\text { amplification (RPA) } \\
\text { combined with Lateral } \\
\text { flow nucleic acid assay } \\
\text { (LFNAA) }\end{array}$ & $\begin{array}{l}\text { Identification of cow, goat, camel } \\
\text { and donkey milk in yak milk }\end{array}$ & Raw milk & $\begin{array}{l}\text { Mitochondrial genome } \\
\text { complete sequence }\end{array}$ & $5 \%$ of yak milk & Wang et al. (2020) \\
\hline $\begin{array}{l}\text { Paper-based DNA } \\
\text { biosensor }\end{array}$ & $\begin{array}{l}\text { Identification of cow species in goat } \\
\text { and sheep dairy products }\end{array}$ & $\begin{array}{l}\text { Binary mixtures of goat- and } \\
\text { sheep-based yogurt samples, with } \\
\text { different proportions of cow } \\
\text { yogurt }\end{array}$ & $\begin{array}{l}\text { Cow species nuclear } \\
\text { targets and sheep, goat } \\
\text { and water buffalo } \\
\text { cytochrome } b \text { gene }\end{array}$ & $\begin{array}{l}0.01 \% \text { of cow } \\
\text { yogurt }\end{array}$ & $\begin{array}{l}\text { Bougadi and } \\
\text { Kalogianni (2020) }\end{array}$ \\
\hline \multicolumn{6}{|l|}{ Breed differentiation } \\
\hline Technique & Objective of the analysis & Type of dairy sample & DNA target & Detection limit & ref \\
\hline RAPD-SCAR & $\begin{array}{l}\text { Identification of adulterant breeds } \\
\text { in milk mixtures and design of } \\
\text { robust breed-specific Sequence } \\
\text { Characterized Amplified Regions } \\
\text { (SCAR) markers to facilitate the } \\
\text { origin of milk determination in } \\
\text { Serra da Estrela cheese }\end{array}$ & Raw milk & Random & - & Cunha et al. (2016) \\
\hline PCR-RFLP & $\begin{array}{l}\text { Differentiation of three Egyptian } \\
\text { goat breeds }\end{array}$ & Blood samples & $\begin{array}{l}\text { myostatin (MSTN) and } \\
\text { prolactin (PRL) genes }\end{array}$ & - & $\begin{array}{l}\text { Abdel-Aziem et al. } \\
\text { (2018) }\end{array}$ \\
\hline PCR-SSCP & $\begin{array}{l}\text { Identification of polymorphisms in } \\
\text { cattle } 2^{\prime}, 5^{\prime} \text { - oligoadenylate } \\
\text { synthase gene }\end{array}$ & Blood samples & $\begin{array}{l}2^{\prime}, 5^{\prime} \text { - oligoadenylate } \\
\text { synthase gene }\end{array}$ & - & Alex et al. (2017) \\
\hline
\end{tabular}

sheep's milk in laboratory made cheeses with different milk admixtures and commercial Italian cheeses, through the amplification of mitochondrial 12s and 16s rRNA genes (Bottero et al., 2003). Deng et al. developed a duplex PCR amplification for detection of bovine milk in camel, horse, and goat milk, obtaining a detection limit of $0.1 \%$ in raw milk mixture. The duplex reaction was performed to detect cow DNA in binary mixtures of raw milk fixed percentage and processed dairy products (freeze-dried, pasteurized, and ultra-high temperature (UHT) sterilized with the same mixtures and commercial samples) through amplification of 16S-RNA genes from camel and cow and D-LOOP genes from horse and goat (Deng et al., 2020).

Real-time PCR or quantitative PCR is a sensitive, reproducible, and high-throughput method for amplification and qualitative and quantitative analysis of an amplicon. Advantages of this method include the reduced time of analysis comparing to conventional PCR and the simplicity to detect simultaneously different amplicons in a single reaction by using different dyes, which can be very useful for detection of different species in dairy products (Pereira et al., 2013) and to determine the origin and quantity of the milk types used in cheese manufacturing(Kemal Seçkin, Yilmaz, \& Tosun, 2017). Additionally, real-time PCR has proved to be more sensitive than conventional PCR when DNA used for amplification is extracted from UHT milk and dairy products with high lipid content, such as cream, butter and cheese (Pirondini et al., 2010). Lopparelli et al. developed a real-time PCR method based on TaqMan minor groove binding (MGB) probe to detect and quantify cow milk addition to buffalo cheeses, through the amplification of cytochrome $b$ and nuclear growth hormone (GH) genes. The developed method presented a detection limit of $0.1 \%$ of cow species (Lopparelli, Cardazzo, Balzan, Giaccone, \& Novelli, 2007). Recently, Liao et al. developed a novel DNA method for DNA extraction from milk powder and presented a qualitative (conventional PCR) and quantitative method (real time PCR based on SYBR Green fluorescent dye) to detect 
adulteration of goat milk powder with cow milk powder, through the amplification of mitochondrial cytochrome $b$ gene. The developed method allowed the detection of cow species in mixtures with as lower as $0.1 \%$ of cow milk powder ( $\mathrm{J}$ Liao, Liu, Ku, et al., 2017).

A reported efficient method for species-specific detection of DNA from four different species (cattle, sheep, goat, water buffalo) in milk and five PDO mozzarella cheeses was used by Reale, Campanella, Merigioli, and Pilla (2008). A detection limit of $0.1 \%$ of cow milk in buffalo milk was estimated after serial dilutions of genomic DNA. The method was based on the amplification of the conserved genomic к-casein gene of the four species referred and subsequent single nucleotide polymorphisms (SNPs) haplotype pattern detection through minisequencing primer extension reaction using fluorescently labelled dideoxynucleotides (ddNTPs) in the ABI Prism SNaPshot ${ }^{\mathrm{TM}}$ Multiplex System. The added ddNTPs were identified by capillary electrophoresis (Reale et al., 2008). This latter technique has become increasingly used over agarose gel electrophoresis for detection of SNPs because of the possibility of automation, flexibility of application (zone electrophoresis, capillary gel electrophoresis, and capillary isoelectric focusing), informatic output and detection sensitivity (since fluorescent tags are used) (F. Pereira et al., 2013).

HRM is a sensitive method that involves amplification of a DNA target by PCR in the presence of a saturation dye, subsequent melting of the amplicons and ultimate analysis and interpretation of the data using a high-resolution equipment. The use of saturation dyes allows labelling of all the PCR product resulting in the detection of all the melting domains. The high-resolution equipment allow a detailed analysis of the melting behaviour, the application of smaller temperature increments and enhanced data acquisition compared to common real-time PCR device (Druml \& Cichna-Markl, 2014). Ganopoulos et al. developed an easy to use and robust HRM-real time PCR based method to detect and quantify bovine, ovine, and caprine species and authenticate Greek PDO Feta cheese. For that, initially they amplified bovine species by real-time PCR using a species-specific primer pair and then used specific primer to amplify the D-loop region and tRNA ${ }^{\text {Lys }}$ for HRM analysis, allowing the detection of $0.1 \%$ of cow milk (Ganopoulos, Sakaridis, Argiriou, Madesis, \& Tsaftaris, 2013). In another study, Agrimonti et al. developed a quadruplex real-time PCR based on SYBR GreenER DNA intercalating fluorescent dye and HRM analysis for rapid identification of DNA of cow, goat, sheep and buffalo in milk admixtures, prepared cheeses and commercial dairy products, and for quantification of cow DNA in these products. The methodology developed by the authors allowed detection of $0.1 \%$ of cow species in cheeses and mixtures of milk (Agrimonti, Pirondini, Marmiroli, \& Marmiroli, 2015).

DNA hybridization is a rapid, sensitive, and specific method that have also been applied for milk authentication and species detection. These assays are based on the hybridization of a known DNA probe to a specific complementary nucleotide DNA sequence on a solid or liquid support. In 2017, Kounelli et al. developed a sensitive method based on a fluorometric DNA hybridization assay on polystyrene microspheres that contain carboxyl groups on their surface, coupled to specific probes for bovine, sheep and goat species. The method was centred in the amplification of mitochondrial cytochrome $b$ gene from those species, allowing detection limits as lower as $0.01 \%$ of bovine milk in binary mixtures of bovine/goat yogurts and $0.05 \%$ proportion in bovine/sheep yogurt mixtures (Kounelli \& Kalogianni, 2017). Beltramo et al. applied a biochip (LCD array) for cattle, goat, and buffalo species identification in milk admixtures, using a method based on the hybridization of biotinylated amplicons specific to cytochrome $b$ oxidase gene of all three species that allowed simultaneous detection of several targets and revealed a sensitivity of $0.1 \%$ (Beltramo et al., 2017).

Bougadi et al. developed a novel paper-based DNA biosensor for detection of cow species in goat and sheep yogurt samples. Briefly, DNA from cow, sheep and goat species was amplified in a PCR reaction using species-specific primers described by Rentsch et al. and Kounelli et al. and originating fragments with 83, 88 and $150 \mathrm{bp}$, respectively. After amplification, each biotinylated product was diluted, denatured, and allowed to hybridize to complementary DNA probes. Pre-hybridized PCR products were placed in contact with functionalized streptavidin gold nanoparticles for visual detection of the species. The presented method allowed the detection of cow species in binary mixtures of yogurt as low as $0.01 \%$ (Bougadi \& Kalogianni, 2020).

PCR-SSCP is one of the simplest and fastest method for determining polymorphisms and mutations between short DNA sequences. This technique is based on the theory that the conformation acquired by a DNA sequence when it is resolved under non-denaturing conditions is based on the sequence length and composition, which results in different migration rates and a consequent specific band pattern for a given species/breed. This method was used by Csikos et al. to identify cattle, buffalo, sheep, and goat DNA in milk and cheese samples of commercial dairy farms in Bosnia and Hungary through the amplification of conserved regions of mitochondrial 12S rRNA, allowing the detection of as low as 3\% of cattle DNA (Csikos et al., 2016).

Ribani et al. firstly applied the Ion Torrent next generation semiconductor-based sequencing (NGS) technology for dairy products authentication. DNA from goat, sheep, cow, and buffalo was PCR amplified using species-specific universal primers (based on $12 \mathrm{~S}$ and $16 \mathrm{~S}$ rRNA mitochondrial genes) and PCR products were sequenced to simultaneously identify the four species. Although the sensitivity of the technique still needs to be fine-tuned in accordance with the background signal obtained from the analytical procedures, the authors were able to detect $10 \%$ of goat milk in a mixture with $90 \%$ of cow milk (Ribani et al., 2018).

Alternative methods to PCR for nucleic acids amplification requiring much simpler equipment as isothermal amplification technologies have been recently developed for dairy products authentication. Isothermal amplification methods include loop-mediated isothermal amplification (LAMP) that may be combined with PCR, strand displacement amplification (SDA), and recombinase polymerase amplification (RPA). LAMP is a technique that allows the specific amplification of several regions of a template DNA through the action of a strand-displacing DNA polymerase. The technique involves the design of 4-6 specific primers that permit the formation of "loop" structures, which facilitate amplification. SDA, in turn, is based on the use of a strand displacement DNA polymerase and a nicking endonuclease. Specific primers are designed to create nicks, which are regenerated through the action of the polymerase. Finally, RPA is a technique that involves the use of a recombinase, which helps the designed primers invade into double-stranded DNA.

Kim et al. developed a rapid duplex LAMP method to simultaneously detect cow and goat milk on-site using a portable fluorescence device. The LAMP assay was combined with PCR amplification of DNA from both species using LAMP primer sets based on the cytochrome $b$ mitochondrial gene. One of the advantages of this method is that DNA extraction can be skyped. The developed method allowed to detect $2 \%$ of cow milk in goat milk binary mixtures and vice versa (Kim \& Kim, 2018).

Particularly, RPA can be operated directly on double stranded DNA without the need for a heating step, allowing rapid, and low cost in situ detection compared with the other referred isothermal amplification methods. Wang et al. developed a method for detection of adulteration in yak milk using RPA technique combined with a novel modified lateral flow nucleic acid assay (LFNAA) with a single-stranded DNA molecule as probe for RPA products detection. Specific RPA primers were designed based on yak mitochondrial genome complete sequence, allowing the exclusive detection of yak species, while DNA extracted from other possible fraudulent species (cow, goat, camel and donkey) did not result in amplification. LFNAA allowed the detection of yak milk in percentage as low as $5 \%$ in mixtures $(5 \%, 10 \%, 20 \%, 50 \%$ and $80 \%$ ) with cow milk (Wang et al., 2020). Although the presented method is innovative, the results obtained at the level of the detection limit are not as lower as the ones obtained with PCR-based methods. 


\subsection{Breed-differentiation techniques}

Although several techniques have been implemented over the years for dairy products authentication (mainly milk and cheese) through species-specific markers identification, few techniques have been developed for breed differentiation in these products (Table 2). Breed differentiation is of utmost importance for traceability in the dairy sector since some products, such as PDO cheeses, present high commercial value and superior nutritional characteristics attributed to the milk composition and quality produced by specific breeds in a given geographical region. However, production of sufficient milk from these breeds to supply the global market may be difficult because of problems related to climatic alterations affecting animal feeding, low milk production associated with some breeds (lactation status) and vegetation seasonality. For those reasons, PDO products adulteration have become frequent, conducting to nutritional, flavour and texture defects attributed to the addition of milk from adulterant breeds.

Breed identification can be challenging mainly due to lack of available sequences in public databases, which hinders the application of several DNA-based techniques. Although the sequencing of the individual's DNA offers the most accurate way for its genetic identification, it is not always feasible and cost affordable. However, there are PCR-based fingerprinting methods that do not require previous knowledge of the sequence of interest and are currently applied for this purpose, such as RAPD and SSCP.

RAPD-PCR is an inexpensive technique that consists in the use of a single arbitrary primer (8-15 nucleotides in length) that will hybridize to the template DNA at random sites and generate a breed-specific fingerprint. For dairy products authentication purposes through the identification of fraudulent milk species, the fragments pattern obtained from adulterant breeds should be compared with the patterns obtained from the legitimate breed with the goal of identifying discriminatory fragments. Those discriminatory fragments are isolated from agarose gel, cloned, and sequenced. Based on that DNA sequence, designated Sequenced Characterized Amplified Region Marker (SCAR), longer and specific primers are designed. As such, RAPD and SCAR techniques used in combination are potential tools for the detection of milk origin in dairy products (Cunha \& Domingues, 2017; Cunha et al., 2016). Cunha et al. (2016) applied the RAPD technique for the detection of adulterant breeds in milk mixtures used for fraudulent production of the Portuguese Serra da Estrela PDO cheese followed by the design of SCAR markers specific to one of the most common breeds used in adulteration of that cheese.

PCR-SSCP analysis, described in the previous section, was used by Alex et al. to investigate the genetic variation within the $2^{\prime}, 5^{\prime}$-oligoadenylate synthetase gene in indigenous and cross-bred cattle of Indian Origin. The polymorphisms identified present an opportunity for genetic variation and reproductive traits that could be possibly used for breed differentiation (Alex et al., 2017).

In another study, Abdel-Aziem et al. developed a PCR-RFPL method that can be used for authentication of Egyptian goat dairy products, since it allows breed differentiation between three breeds (Barki, Damascus and Zaraibi) based on genetic polymorphisms of myostatin (MSTN) and prolactin (PRL) genes (Abdel-Aziem, Mahrous, Abd El-Hafez, \& Abdel Mordy, 2018).

\section{DNA markers and bioinformatics as tools to assist dairy products traceability and authentication}

One of the problems related to DNA-based approaches for food authentication is the lack of procedure standardization and universality. To tackle this question, DNA barcoding emerged as a universal tool for food traceability based on the identification of a standard region in a given genome (called DNA barcode) that is uniquely associated with a specie, breed/variety or individual. The reasons behind the success of the application of DNA barcoding are related with i) DNA variability study attributed to a taxa, ii) standardization of the protocol (from sample collection to the analysis), and iii) bioinformatic approaches to analyse and effectively divulge the information obtained in public databases (Wilson, Sing, \& Jaturas, 2019).

Currently, this technology has been used for food traceability and food mislabelling detection, for example, for fish and seafood products authentication through the development of Fish Barcode of Life Initiative (FISH-BOL) database (Ward, Hanner, \& Hebert, 2009). FISH-BOL data is part of the Barcode of Life Data (BOLD) system, which is considered a robust reference library of DNA barcode. Breed traceability of dairy products, mainly with PDO labels, have become an important matter for authentication of these products. Breeds and geographical origin from which these products are derived have been used as market symbols and have driven rural development. Therefore, productors and brands to which these products are associated have been struggling for certain breeds conservation and biodiversity. Despite the potential application of DNA barcoding for dairy products traceability there are still no studies based only on DNA barcoding. One example of the application of DNA barcoding for milk traceability was described by Ponzoni, Mastromauro, Gianì, and Breviario (2009), where the universal marker for plant DNA barcoding was used to detect traces of plant DNA fragments in raw milk. The authors claim that the identification of those plant DNA fragments could be associated with specific pasture areas and possibly contribute to PDO cheeses traceability and authentication (Ponzoni et al., 2009). DNA barcodes generated through the traditional Sanger sequencing can be analysed (quality check, filtering, reads overlapping and format conversion) using open source tools such as SPIDER (Brown et al., 2012), ClinQC (Pandey, Pabinger, Kriegner, \& Weinhäusel, 2016) and SeqTrace (Stucky, 2012). Recently, an automated pipeline for Sanger sequence DNA barcode analysis, PIPEBAR was developed by Oliveira et al. (Oliveira, Nunes, de Lima, Oliveira, \& Alves, 2018).

The development of DNA barcoding is based on the amplification of short DNA fragments with high interspecific, and low intraspecific variability. The DNA fragments usually applied for animal foodstuffs barcoding belong to the mitochondrial genome, since mitochondrial genes present high copy number, lack introns, exhibit low recombination rate, and are highly conserved at the species level. Moreover, mitochondrial genes can be found practically intact in processed food. The universal barcode for animal species is the cytochrome $c$ oxidase subunit 1 encoding gene $\operatorname{cox} 1$ or COI. Other mitochondrial genes were also suggested as alternatives for barcoding include $c o b$, which encodes for apocytochrome b, 16 rDNA and 12S rDNA gene. However, there is still a lack of agreement on the DNA markers and approaches that should be used to apply DNA barcode for food authentication.

The control region or D-loop, the main noncoding regulatory region for the transcription and replication of mtDNA, has been used to identify genetic polymorphisms and maternal origin of sheep breeds. Liu et al. (2016) studied population genetics and phylogeny of fifteen Tibetan sheep populations based on the complete mtDNA control region. The approach adopted consisted in i) DNA extraction from blood samples, ii) PCR amplification using primers designed based on the sequence of the complete mtDNA D-loop, iii) sequencing of the amplified fragments, and iv) data analysis. For data analysis, Clustal Omega online software was used for multiple alignment, DnaSP (Sequence Polymorphism Software) for diversity parameters calculation, Arlequin software for estimating the genetic differentiation coefficient (GST), Wright's F-statistics of subpopulation within total (FST), gene flow (Nm), molecular variance (AMOVA) test, neutrality tests (Ewens-Watterson test, Chakraborty's test, Tajima's D test, Fu's FS test), and MEGA software for evaluation of phylogenetic and molecular evolutionary relationships, and NETWORK software for the construction of a network based on median-joining method (J. Liu et al., 2016).

Currently, several different DNA markers have been studied for traceability purposes in livestock to differentiate breeds, but the most widely used are microsatellites and SNPs. Microsatellites, or short 
tandem repeats (STRs), are polymorphic DNA motifs (1-6 bp) tandemly repeated that have been commonly used for genetic diversity and structure evaluation of breeds (Ozmen, Kul, \& Gok, 2020), genetic characterization of a breed (Silva et al., 2017) or genetic identification in animals or parentage assessment (Pei et al., 2018). Although these approaches led to the identification of several different STRs, none have been implemented as a tool for breed differentiation or dairy products authentication. Nevertheless, some of the STRs identified can be used further as tools for dairy products and breed traceability. Sardina et al. (2015) identified microsatellites to discriminate among dairy goat breeds bearing in mind the detection of adulteration of Girgentana (Sicilia, Italy) dairy products. The strategy adopted involved i) the extraction of DNA from blood samples of animals from different breeds, ii) DNA extraction from cheese samples, iii) preparation of DNA pools by mixing DNA from the analysed breeds in different proportion, iv) amplification of microsatellite markers chosen according to the International Society for Animal Genetics (ISAG)/Food and Agricultural Organization (FAO), v) statistical analysis using software CERVUS, FSTAT, ARLEQUIN and GENEPOP to evaluate allele frequencies, mean number of alleles, observed and expected heterozygosity, allele richness and polymorphic information content (Sardina et al., 2015).

Currently, STRs are being replaced by SNPs for genetic diversity studies and breed assignments. SNPs are abundant single substitutions of nucleotides that occur at a specific site in a genome that allow higher discrimination power, more informative and less expensive analysis comparatively to STRs (Kawȩ;cka, Gurgul, \& Miksza-Cybulska, 2016). SNPs have been studied to assess parentage (McClure et al., 2018), to assign breeds and evaluate genetic and population diversity (Zwane et al., 2019), and even for phylogenetic and phylogeographic studies (Leaché \& Oaks, 2017). Moreover, SNPs in the SLC27A3 gene (encoding a fatty acid transport protein, FATP3) in sheep were identified and its correlation with nutritional value of milk was assessed. In the study reported by Pecka-Kiełb, Kowalewska-łuczak, Czerniawska-Piątkowska, and Zielak-Steciwko (2020), four SNPs were identified and milk from sheep with TT genotype at SNP4 is characterised by good nutritional value (Pecka-Kiełb et al., 2020). To study the genetic diversity of indigenous Iranian sheep breeds, Moradi, Phua, Hedayat, Khodaei-Motlagh, and Razmkabir (2017) used the SNPs from the mtDNA D-loop region, allowing the classification of the analysed animals into unique mtDNA haplotypes (Moradi et al., 2017).

Next generation sequencing (NGS) combined with new software tools have driven automatic and simultaneous analysis of thousands of SNPs. Nevertheless, there are some drawbacks of the application of these techniques such as the necessity of extraction of good quality DNA for amplification. Several NGS platforms can be used for high throughput DNA sequencing, but the most widely used is Illumina (Haynes, Jimenez, Pardo, \& Helyar, 2019). Currently, there are several open source software for NGS genotype, such as GATK and SAMtools (Maruki \& Lynch, 2017). Although these tools have been very useful for SNP analysis, they require bioinformatic skills and some of them do not have a user-friendly interface. As a user-friendly alternative, an online server for automatic analysis of SNPs and tree construction from whole genome sequencing (WGS) as well as from assembled genomes or contigs, the snpTree, was developed by Leekitcharoenphon et al. (2012). The server integrates available SNPs analysis software, such as SAMtools and MUMmer (Leekitcharoenphon et al., 2012).

BeadArray (BeadChip) technology based on microarrays, developed by Illumina, has also been used for SNPs genotyping from different species, including cattle (BovineSNP50), pigs (PorcineSNP60), dogs (CanineSNP20), and sheep (OvineSNP50). The last one was developed in conjunction with the International Sheep Genomics Consortium (ISGC). An example of the successful use of SNPs for parentage assignment using the OvineSNP50 was reported by Tortereau, Moreno, Tosser-Klopp, Servin, and Raoul (2017), which identified a panel of 249 SNPs derived from a commercial 50K SNP chip. The SNPs identified were used for Blanche du Massif Central breed assignment, resulting in more than
95\% accuracy (Tortereau et al., 2017). Although there is still no established method for dairy products authentication using SNPs, the information obtained from genetic diversity studies may be analysed and eventually applied for this purpose. Nevertheless, populations crossing that resulted in the modern breeds is a complex process characterized by extensive genetic variability, which poses major challenges for distinctive breed markers that can be used for traceability and authenticity purposes. As such, the development of an efficient traceability method based on SNPs must be based on the set of a minimal number of markers that will be able to uniquely assign animals among pure breeds or cross-bred herds.

\section{Conclusion and future trends}

Despite the stricter food safety systems, especially in what concerns food labelling and traceability, the constantly growing and global size of food chains resulted in an increase in food fraud events. In this sense, DNA-based methods for food authentication gained special interest by industries and laboratories due to their sensitivity and reproducibility. However, DNA quality can be influenced by the manufacturing process, extraction method employed, and the chemical composition of the food matrix analysed. Therefore, DNA extraction must be improved and adapted to facilitate downstream analysis. The DNA markers chosen for species/breed detection are also an important factor for PCR success, and in this sense mitochondrial DNA has proven to be a more efficient target than genomic DNA. Food products with high market value, such as PDO cheeses, are the most prone to food fraud by the addition of undeclared species/breed. Despite the several molecular methods developed for the detection of adulterant species, there is still an unmet demand for methods able to detect adulterant breeds, mainly because breed present low genetic variation compared to species. Molecular techniques are advancing towards the development of more sensitive, multiple targets, and high-throughput approaches, allowing on-site authentication and quantification of fraudulent species/breed. Available public databases and bioinformatics revolutionized the analysis of large amount of data and DNA markers identification. Nevertheless, there is still needed progress to connect the discovery of novel DNA markers and the adequate method for detection of adulterant species/ breeds. In the future, techniques like droplet microfluidics, microsphere suspension array technology and digital PCR could become useful for food authentication, given their specificity and multiplicity. Specifically, processing liquids at small scales in microfluidic devices is a promising technology that is being already used to solve issues related with food safety, namely for the detection and quantification of food pathogens. Microsphere suspension array technology is a high throughput and multiplexed technology that allows SNP genotyping, given an important perspective for dairy authentication. Finally, digital PCR has been developed as an alternative method to real-time PCR for absolute quantification and rare allele detection because of its increased resistance to inhibitors, increased precision by using more PCR replicates and capability to analyse complex mixture. This technology is based on the use of a nanofluidic chip, allowing the run of thousands of PCR reactions in parallel and the detection of the presence or absence of an endpoint signal with the help of a TaqMan probe.

\section{Declaration of competing interest}

The authors report no conflict of interest.

\section{Acknowledgments}

This work was supported by the ProDOP Serra da Estrela (PDR2020101-032096) funded by PDR2020 - Programa de Desenvolvimento Rural 2014-2020, Portugal 2020, European Agricultural Fund For Rural Development (EAFRD), and the Portuguese Foundation for Science and Technology (FCT) under the scope of the strategic funding of UIDB/ 
04469/2020 and the MIT-Portugal Program (Ph.D. Grant PD/BD/ $128247 / 2016$ to JTC).

\section{References}

Abdel-Aziem, S. H., Mahrous, K. F., Abd El-Hafez, M. A. M., \& Abdel Mordy, M. (2018). Genetic variability of myostatin and prolactin genes in popular goat breeds in Egypt. Journal of Genetic Engineering and Biotechnology, 16(1), 89-97. https://doi.org/ 10.1016/j.jgeb. 2017.10.005

Abdel-Rahman, S., \& Ahmed, M. (2007). Rapid and sensitive identification of buffalo's, cattle's and sheep's milk using species-specific PCR and PCR-RFLP techniques. Food Control, 18(10), 1246-1249. https://doi.org/10.1016/j.foodcont.2006.08.003

Agrimonti, C., Bottari, B., Sardaro, M. L. S., \& Marmiroli, N. (2019). Application of realtime PCR (qPCR) for characterization of microbial populations and type of milk in dairy food products. Critical Reviews in Food Science and Nutrition, 59(3), 423-442. https://doi.org/10.1080/10408398.2017.1375893

Agrimonti, C., Pirondini, A., Marmiroli, M., \& Marmiroli, N. (2015). A quadruplex PCR (qxPCR) assay for adulteration in dairy products. Food Chemistry, 187, 58-64. https://doi.org/10.1016/j.foodchem.2015.04.017

Alex, R., Ramesha, K. P., Singh, U., Kumar, S., Alyethodi, R. R., Deb, R., et al. (2017). Association analysis of novel polymorphisms in $2^{\prime}, 5^{\prime}$-oligoadenylate synthetase gene with reproductive traits in indigenous and cross-bred cattle of Indian Origin. Reproduction in Domestic Animals, 1-8. https://doi.org/10.1111/rda.13129

Bai, W. L., Yin, R. H., Zhao, S. J., Dou, Q. L., Yang, J. C., Jiang, W. Q., et al. (2009). Rapid detection of bovine milk in yak milk using a polymerase chain reaction technique. Journal of Dairy Science, 92(4), 1354-1360. https://doi.org/10.3168/jds.2008-1727

Bánáti, D. (2014). European perspectives of food safety. Journal of the Science of Food and Agriculture, 94(10), 1941-1946. https://doi.org/10.1002/jsfa.6611

Barron, L. J. R., Aldai, N., Virto, M., \& de Renobales, M. (2017). Cheeses with protected land- and tradition-related labels: Traceability and authentication. In P. Papademas, \& T. Bintsis (Eds.), Global cheesemaking technology: Cheese quality and characteristics (1st ed., pp. 100-119). John Wiley \& Sons Ltd. https://doi.org/10.1002/ 9781119046165.ch0e.

Beltramo, C., Riina, M. V., Colussi, S., Campia, V., Maniaci, M. G., Biolatti, C., et al. (2017). Validation of a DNA biochip for species identification in food forensic science. Food Control, 78, 366-373. https://doi.org/10.1016/j. foodcont.2017.03.006

Bottero, M. T., Civera, T., Nucera, D., Rosati, S., Sacchi, P., \& Turi, R. M. (2003). A multiplex polymerase chain reaction for the identification of cows', goats' and sheep's milk in dairy products. International Dairy Journal, 13(4), 277-282. https:// doi.org/10.1016/S0958-6946(02)00170-X

Bougadi, E. T., \& Kalogianni, D. P. (2020). Paper-based DNA biosensor for food authenticity testing. Food Chemistry, 322, Article 126758. https://doi.org/10.1016/j foodchem.2020.126758

Brown, S. D. J., Collins, R. A., Boyer, S., Lefort, M. C., Malumbres-Olarte, J., Vink, C. J., et al. (2012). Spider: An R package for the analysis of species identity and evolution, with particular reference to DNA barcoding. Molecular Ecology Resources, 12(3), 562-565. https://doi.org/10.1111/j.1755-0998.2011.03108.x

Cottenet, G., Blancpain, C., \& Golay, P. A. (2011). Simultaneous detection of cow and buffalo species in milk from China, India, and Pakistan using multiplex real-time PCR. Journal of Dairy Science, 94(8), 3787-3793. https://doi.org/10.3168/jds.20114195

Csikos, A., Hodzic, A., Pasic-Juhas, E., Javor, A., Hrković-Porobija, A., Goletic, T., et al. (2016). Applicability and sensitivity of PCR-SSCP method for milk species identification in cheese. Acta Alimentaria, 45(1), 69-76. https://doi.org/10.1556/ 066.2016.45.1.9

Cunha, J. T., \& Domingues, L. (2017). RAPD/SCAR approaches for identification of adulterant breeds' milk in dairy products. In L. Domingues (Ed.), Pcr: Methods and protocols, methods in molecular biology (1st ed., Vol. 1620, pp. 183-193). Springer Science+Business Media LLC. https://doi.org/10.1007/978-1-4939-7060-5.

Cunha, J. T., Ribeiro, T. I. B., Rocha, J. B., Nunes, J., Teixeira, J. A., \& Domingues, L. (2016). RAPD and SCAR markers as potential tools for detection of milk origin in dairy products: Adulterant sheep breeds in Serra da Estrela cheese production. Food Chemistry, 211, 631-636. https://doi.org/10.1016/j.foodchem.2016.05.109

Dalmasso, A., Civera, T., La Neve, F., \& Bottero, M. T. (2011). Simultaneous detection of cow and buffalo milk in mozzarella cheese by Real-Time PCR assay. Food Chemistry, 124(1), 362-366. https://doi.org/10.1016/j.foodchem.2010.06.017

Deng, L., Li, A., Gao, Y., Shen, T., Yue, H., Miao, J., et al. (2020). Detection of the bovine milk adulterated in camel, horse, and goat milk using duplex PCR. Food Analytical Methods, 13(2), 560-567. https://doi.org/10.1007/s12161-019-01678-2

Di Domenico, M., Di Giuseppe, M., Wicochea Rodríguez, J. D., \& Cammà, C. (2017). Validation of a fast real-time PCR method to detect fraud and mislabeling in milk and dairy products. Journal of Dairy Science, 100(1), 106-112. https://doi.org/10.3168/ jds.2016-11695

Di Pinto, A., Conversano, M. C., Forte, V. T., Novello, L., \& Tantillo, G. M. (2004). Detection of cow milk in buffalo "mozzarella" by polymerase chain reaction (PCR) assay. Journal of Food Quality, 27(6), 428-435. https://doi.org/10.1111/j.17454557.2004.00662.x

Di Pinto, A. Di, Forte, V. T., Guastadisegni, M. C., Martino, C., Schena, F. P., \& Tantillo, G. (2007). A comparison of DNA extraction methods for food analysis. Food Control, 18 (1), 76-80. https://doi.org/10.1016/j.foodcont.2005.08.011

Díaz, I. L. C., Alonso, I. G., Fajardo, V., Martín, I., Hernández, P., Lacarra, T. G., et al. (2007). Application of a polymerase chain reaction to detect adulteration of ovine cheeses with caprine milk. European Food Research and Technology, 225(3-4), 345-349. https://doi.org/10.1007/s00217-006-0421-y
Downey, G. (2016). In G. Downey (Ed.), Advances in food authenticity testing (1st ed., pp. 376-399). Woodhead Publishing. https://doi.org/10.1017/ CBO9781107415324.004.

Druml, B., \& Cichna-Markl, M. (2014). High resolution melting (HRM) analysis of DNA its role and potential in food analysis. Food Chemistry, 158, 245-254. https://doi. org/10.1016/j.foodchem.2014.02.111

D'Angelo, F., Santillo, A., Sevi, A., \& Albenzio, M. (2007). A simple salting-out method for DNA extraction from milk somatic Cells: Investigation into the goat CSN1S1 gene. Journal of Dairy Science, 90(7), 3550-3552. https://doi.org/10.3168/jds.20070149

Eusebi, P. G., Martinez, A., \& Cortes, O. (2020). Genomic tools for effective conservation of livestock breed diversity. Diversity, 12(1), 1-16. https://doi.org/10.3390/ d12010008

Feligini, M., Bonizzi, I., Curik, V., Parma, P., Greppi, G., \& Enne, G. (2005). Detection of adulteration in Italian mozzarella cheese using mitochondrial DNA templates as biomarkers. Food Technology and Biotechnology, 43, 91-95.

Ganopoulos, I., Sakaridis, I., Argiriou, A., Madesis, P., \& Tsaftaris, A. (2013). A novel closed-tube method based on high resolution melting (HRM) analysis for authenticity testing and quantitative detection in Greek PDO Feta cheese. Food Chemistry, 141(2), 835-840. https://doi.org/10.1016/j.foodchem.2013.02.130

Golinelli, L. P., Carvalho, A. C., Casaes, R. S., Lopes, C. S. C., Deliza, R., Paschoalin, V. M. F., et al. (2014). Sensory analysis and species-specific PCR detect bovine milk adulteration of frescal (fresh) goat cheese. Journal of Dairy Science, 97 (11), 6693-6699. https://doi.org/10.3168/jds.2014-7990

Gonçalves, J., Pereira, F., Amorim, A., \& van Asch, B. (2012). New method for the simultaneous identification of cow, sheep, goat, and water buffalo in dairy products by analysis of short species-specific mitochondrial DNA targets. Journal of Agricultural and Food Chemistry, 60(42), 10480-10485. https://doi.org/10.1021/ jf3029896

Guo, L., Qian, J.-P., Guo, Y.-S., Hai, X., Liu, G.-Q., Luo, J. X., et al. (2018). Simultaneous identification of bovine and equine DNA in milks and dairy products inferred from triplex TaqMan real-time PCR technique. Journal of Dairy Science, 101(8), 6776-6786. https://doi.org/10.3168/jds.2018-14408

Haynes, E., Jimenez, E., Pardo, M. A., \& Helyar, S. J. (2019). The future of NGS (Next Generation Sequencing) analysis in testing food authenticity. Food Control, 101, 134-143. https://doi.org/10.1016/j.foodcont.2019.02.010

Kawecka, A., Gurgul, A., \& Miksza-Cybulska, A. (2016). The use of SNP microarrays for biodiversity studies of sheep - a review. Annals of Animal Science, 16(4), 975-987. https://doi.org/10.1515/aoas-2016-0017

Kemal Seçkin, A., Yilmaz, B., \& Tosun, H. (2017). Real-time PCR is a potential tool to determine the origin of milk used in cheese production. Lebensmittel-Wissenschaft und -Technologie- Food Science and Technology, 77, 332-336. https://doi.org/10.1016/j. lwt.2016.11.065

Kim, M. J., \& Kim, H. Y. (2018). Direct duplex real-time loop mediated isothermal amplification assay for the simultaneous detection of cow and goat species origin of milk and yogurt products for field use. Food Chemistry, 246, 26-31. https://doi.org/ 10.1016/j.foodchem.2017.11.014

Kounelli, M. L., \& Kalogianni, D. P. (2017). A sensitive DNA-based fluorometric method for milk authenticity of dairy products based on spectrally distinct microspheres. European Food Research and Technology, 243(10), 1773-1781. https://doi.org/ 10.1007/s00217-017-2882-6

Kovačević, N. (2016). Magnetic beads based nucleic acid purification for molecular biology applications. In M. Mićić (Ed.), Sample preparation techniques for soil, plant and animal samples, springer protocols handbooks (1st ed., pp. 53-67). New York: Springer Science+Business Media. https://doi.org/10.1007/978-1-4939-3185-9.

Leaché, A. D., \& Oaks, J. R. (2017). The utility of single nucleotide polymorphism (SNP) data in phylogenetics. Annual Review of Ecology, Evolution and Systematics, 48(1), 69-84. https://doi.org/10.1146/annurev-ecolsys-110316-022645

Leekitcharoenphon, P., Kaas, R. S., Thomsen, M. C. F., Friis, C., Rasmussen, S., \& Aarestrup, F. M. (2012). snpTree-a web-server to identify and construct SNP trees from whole genome sequence data. BMC Genomics, 13(7), 1-8. https://doi.org/ 10.1186/1471-2164-13-s7-s6

Liao, J., Gao, J., Ku, T., \& Liu, Y. (2018). Assessment of milk quality during storage based on DNA extracted from milk. CyTA - Journal of Food, 16(1), 786-792. https://doi. org $/ 10.1080 / 19476337.2018 .1474265$

Liao, J., \& Liu, Y. (2018). Purification procedures meaningfully influence DNA quantification in milk. Lebensmittel-Wissenschaft \& Technologie, 94, 8-12. https://doi. org/10.1016/j.lwt.2018.04.031

Liao, J., Liu, Y. F., Ku, T., Liu, M. H., \& Huang, Y. (2017). Qualitative and quantitative identification of adulteration of milk powder using DNA extracted with a novel method. Journal of Dairy Science, 100(3), 1657-1663. https://doi.org/10.3168/ jds.2016-11900

Liao, J., Liu, Y. F., Yang, L., Li, F. P., \& Sheppard, A. M. (2017). Development of a rapid mitochondrial DNA extraction method for species identification in milk and milk products. Journal of Dairy Science, 100(9), 7035-7040. https://doi.org/10.3168/ jds.2017-12653

Liao, J., Yang, L., Sheppard, A. M., \& Liu, Y. F. (2018). Comparison of DNA quality in raw and reconstituted milk during sterilization. Journal of Dairy Science, 101(1), 147-153. https://doi.org/10.3168/jds.2017-13461

Lipkin, E., Shalom, A., Khatib, H., Soller, M., \& Friedmann, A. (1993). Milk as a source of deoxyribonucleic acid and as a substrate for the polymerase chain reaction. Journal of Dairy Science, 76(7), 2025-2032. https://doi.org/10.3168/jds.S0022-0302(93) 77536-0

Liu, J., Ding, X., Zeng, Y., Yue, Y., Guo, X., Guo, T., et al. (2016). Genetic diversity and phylogenetic evolution of Tibetan sheep based on mtDNA D-loop sequences. PloS One, 11(7), Article e0159308. https://doi.org/10.1371/journal.pone.0159308 
Liu, Y. F., Gao, J. L., Yang, Y. F., Ku, T., \& Zan, L. S. (2014). Novel extraction method of genomic DNA suitable for long-fragment amplification from small amounts of milk. Journal of Dairy Science, 97(11), 6804-6809. https://doi.org/10.3168/jds.20148066

López-Calleja, I., Alonso, I. G., Fajardo, V., Rodríguez, M. A., Hernández, P. E., García, T., et al. (2005). PCR detection of cows' milk in water buffalo milk and mozzarella cheese. International Dairy Journal, 15(11), 1122-1129. https://doi.org/10.1016/j. idairyj.2004.12.003

López-Calleja, I., González, I., Fajardo, V., Martín, I., Hernández, P. E., García, T., et al. (2005). Application of polymerase chain reaction to detect adulteration of sheep's milk with goats' milk. Journal of Dairy Science, 88(9), 3115-3120. https://doi.org/ 10.3168/jds.S0022-0302(05)72993-3

López-Calleja, I., González, I., Fajardo, V., Martín, I., Hernández, P., García, T., et al. (2007). Quantitative detection of goats' milk in sheep's milk by real-time PCR. Food Control, 18(11), 1466-1473. https://doi.org/10.1016/j.foodcont.2006.11.006

Lopparelli, R. M., Cardazzo, B., Balzan, S., Giaccone, V., \& Novelli, E. (2007). Real-time TaqMan polymerase chain reaction detection and quantification of cow DNA in pure water buffalo mozzarella cheese: Method validation and its application on commercial samples. Journal of Agricultural and Food Chemistry, 55(9), 3429-3434. https://doi.org/10.1021/jf0637271

Mafra, I., Roxo, Á., Ferreira, Isabel M. P. L. V. O., \& Oliveira, M. B. P. P. (2007). A duplex polymerase chain reaction for the quantitative detection of cows' milk in goats' milk cheese. International Dairy Journal, 17(9), 1132-1138. https://doi.org/10.1016/j. idairyj.2007.01.009

Maruki, T., \& Lynch, M. (2017). Genotype calling from population-genomic sequencing data. G3: Genes, Genomes, Genetics, 7(5), 1393-1404. https://doi.org/10.1534/ g3.117.039008

Maškova, E., \& Paulíčková, I. (2006). PCR-based detection of cow's milk in goat and sheep cheeses marketed in the Czech Republic. Czech Journal of Food Sciences, 24, 127-132.

Maudet, C., \& Taberlet, P. (2001). Detection of cows' milk in goats' cheeses inferred from mitochondrial DNA polymorphism. Journal of Dairy Research, 68(2), 229-235. https://doi.org/10.1017/S0022029901004794

McClure, M. C., McCarthy, J., Flynn, P., McClure, J. C., Dair, E., O'Connell, D. K., et al. (2018). SNP data quality control in a National Beef and Dairy Cattle system and highly accurate SNP based parentage verification and identification. Frontiers in Genetics, 9, 1-14. https://doi.org/10.3389/fgene.2018.00084

Mendes Silva, D., \& Domingues, L. (2015). On the track for an efficient detection of Escherichia coli in water: A review on PCR-based methods. Ecotoxicology and Environmental Safety, 113, 400-411. https://doi.org/10.1016/j.ecoenv.2014.12.015

Moghaddaszadeh-Ahrabi, S., Farajnia, S., Rahimi-Mianji, G., \& Nejati-Javaremi, A. (2012). Application of whole genome amplification technique for genotype Analysis of bovine embryos. World Academy of Science, Engineering and Technology, 61, 531-534. https://doi.org/10.5281/zenodo.1332810

Moradi, M. H., Phua, S. H., Hedayat, N., Khodaei-Motlagh, M., \& Razmkabir, M. (2017) Haplotype and genetic diversity of mtDNA in indigenous iranian sheep and an insight into the history of sheep domestication. Journal of Agricultural Science and Technology A, 19(3), 591-601.

Oliveira, R. R. M., Nunes, G. L., de Lima, T. G. L., Oliveira, G., \& Alves, R. (2018). PIPEBAR and OverlapPER: Tools for a fast and accurate DNA barcoding analysis and paired-end assembly. BMC Bioinformatics, 19(1), 1-10. https://doi.org/10.1186/ s12859-018-2307-y

Ozmen, O., Kul, S., \& Gok, T. (2020). Determination of genetic diversity of the Akkaraman sheep breed from Turkey. Small Ruminant Research (Vol. 182). https:// doi.org/10.1016/j.smallrumres.2019.10.009

Pandey, R. V., Pabinger, S., Kriegner, A., \& Weinhäusel, A. (2016). ClinQC: A tool for quality control and cleaning of sanger and NGS data in clinical research. BMC Bioinformatics, 17(1), 56. https://doi.org/10.1186/s12859-016-0915-y

Pecka-Kiełb, E., Kowalewska-łuczak, I., Czerniawska-Piątkowska, E., \& ZielakSteciwko, A. E. (2020). Effects of single nucleotide polymorphisms in the SLC27A3 gene on the nutritional value of sheep milk. Animals, 10(4), 1-11. https://doi.org/ 10.3390/ani10040562

Pei, J., Bao, P., Chu, M., Liang, C., Ding, X., Wang, H., et al. (2018). Evaluation of 17 microsatellite markers for parentage testing and individual identification of domestic yak (Bos grunniens). PeerJ, 6, Article e5946. https://doi.org/10.7717/peerj.5946

Pereira, F., Amorim, A., \& Asch, B. van (2013). Genetic and DNA-based techniques. In M. de la Guardia, \& A. Gonzálvez (Eds.), Comprehensive analytical chemistry (Vol. 60 pp. 195-220). Elsevier B.V.

Pirondini, A., Bonas, U., Maestri, E., Visioli, G., Marmiroli, M., \& Marmiroli, N. (2010). Yield and amplificability of different DNA extraction procedures for traceability in the dairy food chain. Food Control, 21(5), 663-668. https://doi.org/10.1016/j. foodcont.2009.10.004
Plath, A., Krause, I., \& Einspanier, R. (1997). Species identification in dairy products by three different DNA-based techniques. Zeitschrift Fr Lebensmitteluntersuchung Und -Forschung A, 205(6), 437-441. https://doi.org/10.1007/s002170050195

Ponzoni, E., Mastromauro, F., Gianì, S., \& Breviario, D. (2009). Traceability of plant diet contents in raw cow milk samples. Nutrients, 1(2), 251-262. https://doi.org/ 10.3390/nu1020251

Psifidi, A., Dovas, C. I., \& Banos, G. (2010). A comparison of six methods for genomic DNA extraction suitable for PCR-based genotyping applications using ovine milk samples. Molecular and Cellular Probes, 24(2), 93-98. https://doi.org/10.1016/j. mcp.2009.11.001

Reale, S., Campanella, A., Merigioli, A., \& Pilla, F. (2008). A novel method for species identification in milk and milk-based products. Journal of Dairy Research, 75(1), 107-112. https://doi.org/10.1017/S0022029907003020

Rentsch, J., Weibel, S., Ruf, J., Eugster, A., Beck, K., \& Köppel, R. (2013). Interlaboratory validation of two multiplex quantitative real-time PCR methods to determine species DNA of cow, sheep and goat as a measure of milk proportions in cheese. European Food Research and Technology, 236(1), 217-227. https://doi.org/10.1007/s00217012-1880-y

Ribani, A., Schiavo, G., Utzeri, V. J., Bertolini, F., Geraci, C., Bovo, S., et al. (2018). Application of next generation semiconductor based sequencing for species identification in dairy products. Food Chemistry, 246, 90-98. https://doi.org/ 10.1016/j.foodchem.2017.11.006

Sajali, N., Wong, S. C., Hanapi, U. K., Jamaluddin, A. B. S., Tasrip, N. A., \& Mohd Desa, M. N. (2018). The challenges of DNA extraction in different assorted food matrices: A review. Journal of Food Science, 83(10), 2409-2414. https://doi.org/ 10.1111/1750-3841.14338

Sardina, M. T., Tortorici, L., Mastrangelo, S., Di Gerlando, R., Tolone, M., \& Portolano, B. (2015). Application of microsatellite markers as potential tools for traceability of Girgentana goat breed dairy products. Food Research International, 74, 115-122. https://doi.org/10.1016/j.foodres.2015.04.038

Schrader, C., Schielke, A., Ellerbroek, L., \& Johne, R. (2012). PCR inhibitors - occurrence, properties and removal. Journal of Applied Microbiology, 113(5), 1014-1026. https:// doi.org/10.1111/j.1365-2672.2012.05384.x

Silva, P., Dematawewa, C. M. B., Kurukulasuriya, M., Utsunomiya, Y. T., Garcia, J. F., Pichler, R., et al. (2017). Genetic diversity analysis of major Sri Lankan goat populations using microsatellite and mitochondrial DNA D-loop variations. Small Ruminant Research, 148, 51-61. https://doi.org/10.1016/j. smallrumres.2016.12.030

Spink, J., Bedard, B., Keogh, J., Moyer, D. C., Scimeca, J., \& Vasan, A. (2019). International survey of food fraud and related terminology: Preliminary results and discussion. Journal of Food Science, 84(10), 2705-2718. https://doi.org/10.1111/ 1750-3841.14705

Stadler, R. H., Tran, L. A., Cavin, C., Zbinden, P., \& Konings, E. J. M. (2016). Analytical approaches to verify food integrity: Needs and challenges. Journal of AOAC International, 99(5), 1135-1144. https://doi.org/10.5740/jaoacint.16-0231

Stucky, B. J. (2012). SeqTrace: A graphical tool for rapidly processing DNA sequencing chromatograms. Journal of Biomolecular Techniques: Journal of Biochemistry, 23(3), 90-93. https://doi.org/10.7171/jbt.12-2303-004

Tortereau, F., Moreno, C. R., Tosser-Klopp, G., Servin, B., \& Raoul, J. (2017). Development of a SNP panel dedicated to parentage assignment in French sheep populations. BMC Genetics, 18(1), 1-11. https://doi.org/10.1186/s12863-017-05182

Wang, Z., Li, T., Yu, W., Qiao, L., Yang, S., \& Chen, A. (2020). A low-cost novel lateral flow nucleic acid assay (LFNAA) for yak milk authentication. LebensmittelWissenschaft \& Technologie, 122, Article 109038. https://doi.org/10.1016/j. lwt.2020.109038

Ward, R. D., Hanner, R., \& Hebert, P. D. N. (2009). The campaign to DNA barcode all fishes, FISH-BOL. Journal of Fish Biology, 74(2), 329-356. https://doi.org/10.1111/ j.1095-8649.2008.02080.x

Wilson, J. J., Sing, K. W., \& Jaturas, N. (2019). DNA barcoding: Bioinformatics workflows for beginners. In Encyclopedia of bioinformatics and computational biology (Vol. 3, pp. 985-995). https://doi.org/10.1016/B978-0-12-809633-8.20468-8

Yudin, N. S., Lukyanov, K. I., Voevoda, M. I., \& Kolchanov, N. A. (2016). Application of reproductive technologies to improve dairy cattle genomic selection. Russian Journal of Genetics: Applied Research, 6(3), 321-329. https://doi.org/10.1134/ S207905971603014X

Zwane, A. A., Schnabel, R. D., Hoff, J., Choudhury, A., Makgahlela, M. L., Maiwashe, A., et al. (2019). Genome-wide SNP discovery in indigenous cattle breeds of South Africa. Frontiers in Genetics, 10(273), 1-16. https://doi.org/10.3389/ fgene.2019.00273 